\title{
San Juan de la Cruz, místico de frontera
}

En tiempo de san Juan de la Cruz, todo había cambiado. El nominalismo, la reforma protestante y el renacimiento obligaban a repensar todos los problemas a una luz humanista. Había cambiado el mundo físico (Copérnico, Colón). También habían cambiado las condiciones de la cultura (Bácón, Gutenberg, Ockham, Leonardo, etč.). Como consecuencia del dogmatismo ingenuo, se había propagado el criticismo y el escepticismo (Montaigne): ya no interesaba el quid scis, sino el unde scis. También había cambiado el mundo espiritual. El renacimiento imponía el afán de libertad y el culto de la personalidad. Lutero imponía el libre examen. Descartes imponía el uprincipio de interioridad". Muchos individuos y colectividades continuaban viviendo en el pasado, como Quijotes, pero su postura no iba a detener la evölución del mundo. La transformación dé Castilla se había desencadenado cọn los Reyes Católicos, y los acontecimientos se precipitaban. El descubrimiénto de América, el impęrialismo de Carlos I, la emigración estimulada por la crịis económica, el conflicto religioso de los conversos, judíos y moriscos, la lucha entre los diferentes estamentos sociales, el alistamiento de misiones para América, la reforma moral y religiosa, la extraordinaria y repentina floración literaria, los libros venidos del norte y del sur, colocaban al hombre castellano ante una situación enteramente nueva.

Dentro de ese complejo de fenómenos surgen la «mística castellana» y la «reforma castellana de santa Teresa de Jesús». En cuanto a la mística, es evidente el triunfo de la experiencia y de la psicología. Sin duda el problema de las "fuentes» tiene gran importancia. Asimismo tiene gran importancia el método de análisis estructural que hoy está en boga. Pero Juan de la Cruz es uél y su circunstancia»: sus "Obras» fueron genéticamente compuestas, como fruto de una tradición viva, desde luego, pero también de una «époća» inspirada, y de una «personalidad» condicionada en el tiempo y en el espacio. Juan de la Cruz no es ya un «medieval»; pero tampoco es todavía un hombre totalmente «moderno». Por eso lo presentamos como «místico de frontera». En cuanto al carmelo, y a la visión que el santo tuvo del carmelo, el problema es todavía más estricto, más condicionado por la circunstancia. Teresa de Jesús quería vivir como los "Padres del Yermo»; pero eso era imposible en Avila. Su «vuelta a lo primitivo» se convirtió pues, en un grito revolucionario y aguerrido. Juan de la Cruz lo vivió en su propia carne. 


\section{La frontera}

Juan de la Cruz, encandilado por un ideal que cambiaba de sentido la Cartuja aceptó el desafío, como uno de aquellos castellanos que se alistaban para todo, y sabían morir sin desdecirse. Por otra parte, la experiencia era ya un auténtico clamor público: Teresa de Jesús había ido con su alma a cuestas, peregrinando de confesonario en confesonario: los "teólogos», que se jactaban de estar en posesión de los criterios, sudaban más que ella, y había tantas sentencias como cabezas. La santa, dotada de una vitalidad exhuberante, de un clásico buen humor, y de gran santidad, no cesa de bendecir a sus consejeros... pero es claro que ella misma tuvo que irse resolviendo sus problemas, a fuerza de buscar guías de almas. Juan de la Cruz, convocado a ese desafío, se encuentra así con la "frontera» experimental.

Cuando Teresa llamó a Juan su Senequita no hacia un simple donaire. Dentro del donaire había una seriedad rigurosa, una definición científica. La mística inaugurada por Teresa y por sus carmelos necesitaba una exploración semejante a la de la América de los aventureros. Juan, confesor de Teresa durante algunos años, dueño de una profunda e inteligente experiencia personal, hubo de ir recibiendo la confesión de aquellos $y$.aquellas, que venían a consultarle sobre "su caso». Oía hablar de teólogos y alumbrados, de inquisidores y consultores, de embaucadores y embaucados, de arrobamientos y abobamientos, de religión y de superstición, de cumbres místicas y de excursiones nocturnas. Se convirtió en un especialista, y se sintió llamado a ejercer su "santo oficio» con diligencia y competencia. Todos los problemas de la teología del apostclado, de la vida común y claustral, de la soledad del corazón, necesitaban revisión y tenía que ajustarse a un tipo de mística, que se identificaba con el modo de vivir soñado por Teresa. La mística era ya inconfundible, diferente de la que hubiera podido sugerir la Edad Media, incluso en los representantes I enanos y hermanos de la nueva piedad. Porque la frontera ponía a la vista lo que debió ser una "mística barroca», en aquellas circunstancias de tiempo y de lugar. $Y$ el barroco incipiente significaba ya un mundo entero, muy diferente del pasado.

Juan construyó, pues, un sistema ecléctico, muy complejo, muy influido por el agustinismo, por el areopagita, por los renanos (quizá mediante Laredo) $y$, por la mística musulmana. Esa «mística castellana» es una antropología teológica y no una teología pura. En cierto modo, es una ruptura con la antigüedad, que se había sujetado siempre a los métodos objetivistas griegos (Platón, Aristóteles y Plotino) y así quedaba condicionada por ellos.

\section{Un nuevo camino de la mística}

El año 1919 A. Magner intervino en la discusión Pouiain-Saudreau, que 
parecía condenada a un callejón sin salida. Sus estudios, muy significativos ', al plantear de raíz el problema místico, distinguían "dos caminos», uno viejo y otro nuevo. El camino nuevo se refería a la mística de santa Teresa, es decir, a la mística castellana. En verdad que el autor parecía excesivamente limitado y condicionado: 1) separaba la mística natural de la sobrenatural, no sólo en dos pisos incomunicables, sino que dejaba la mística sobrenatural a merced de una especulación abstracta, en oposición a su propio principio de experiencia; 2) no daba suficiente importancia a la "sociología de la mística», y así olvidaba uno de los aspectos esenciales, el mensaje, el "carisma» de Teresa y de Juan de la Cruz; 3) ponía la esencia de la mística en el amor, sin pruebas suficientes; así oponía el cristianismo a Grecia como posturas contradictorias e incompatibles; 4) su fidelidad al tomismo le llevaba a comprometerse con el aristotelismo, y asi se encerraba también él en el callejón sin salida; 5) queriendo retener la parte de verdad que proponían Poulain y Saudreau, quedaba emparedado en la misma controversia, sin la posibilidad de superarla.

A pesar de tales limitaciones, la postura de Mager era clara, firme, y provocó una sana reacción. Desde el título de sus estudios, aceptaba la posibilidad de comenzar por los métodos experimentales. Toda mística describirá los fenómenos místicos, que son su "objeto formal»; por ende, la base es una auténtica "fenomenología» ${ }^{2}$. No es preciso recurrir a los tecnicismos de la fenomenología actual; basta puntualizar bien el primer cometido de una mística doctrinal, la mera descripción psicológica, científica, sobre la cual han de tener competencia en primer término los psicólogos y los sociólogos. Los juicios de valor y los juicios sobre las causas, o discreción de espíritus, son un cometido diferente de la experiencia mística, y vendrán a continuación ${ }^{3}$. Pre-

1. MAGER, A., "Zur Wesensbestimmung der Mystik», en Benedictinische Monatschrift, 1919; "Alte und neue Wege in der Mystik», en la misma revista y en el mismo año.

2. Así quería superar Mager la postura tradicional, que imponía el método deductivo, tomando como punto de partida la "visión beatífica», e incluso una via media en la que se combinaban ambos métodos, como la presentaba, por ejemplo Grabmann M., Wesen und Grundlagen der katolischen Mystik, 2 ed. München, 1923) como si fuera indiferente utilizar uno u otro, o como si no hubiese un método "propio» de utilizar esos dos métodos. Así Mager preguntaba: «Qué es la Mística? El que esa pregunta vuelva a hacerse sin cesar demuestra que las respuestas dadas hasta hoy son poco convincentes... Para el hombre actual significa que el planteamiento no nace de intereses teoréticos o científicos, sino de intereses prácticos y necesidades religiosas" Mager, "Zur Wesensbestimmung...» p. 129).

3. La objeción contra Mager era inevitable: comenzar por la descripción psicológica de fenómenos individuales, sin encuadrarse en unormas objetivas» significa condenar la Mística al capricho individual. Mager se defendió bien, ya que tal objeción prueba demasiado, y puede alegarse contra todas las disciplinas. En lo que no acierta Mager es en proponer el amor como esencia de la mística católica. Eso ya lo había hecho Plotino, sin ser cristiano, y ya lo habian hecho los cristianos, a partir del IV Evangelio quien dice: "Haec est vita aeterna, ut videant. San Agustín, y con él la Edad Media había insistido en colocar la esencia del hombre en la razón en una "visión») beatífica; si la "escuela franciscana» acentuó el amor, lo hizo por su aristotelismo, oponiendo el amor a la inteligencia como «facultades» realmente distintas del alma, pues tales distinciones no caben, si las potencias son «personales» a veces, como lo entendía san Agustín. Sin duda que las 
cisamente por eso tenía tanta importancia, a juicio de Mager, la mística teresiana, por su vivacidad, detalle, espontaneidad, imparcialidad. Aunque Mager no estudiaba los rasgos de la mística musulmana, ni el positivismo de un Bacón de Verulano ${ }^{4}$, daba pie para pensar en una mística nueva, y provocar reacciones a favor $y$ en contra de la misma.

\section{Actualidad de san Juan de la Cruz}

Nadie discute la actualidad del místico castellano ${ }^{5}$, pero conviene puntualizar la razón de la misma, ya que el término «actualidad» apunta a una razón "de hoy», y no sólo a una razón de "siempre» ${ }^{6}$. Se supone pues que hay razones específicas de actualidad ${ }^{7}$ y este era el tema de uno de los estudios

descripciones de santa Teresa tienen algunas ventajas sobre las de san Juan de la Cruz por su espontaneidad y falta de prejuicios, pero también las de san Juan tienen otras ventajas, por ser obra reflexiva de teólogo, que conoce las dificultades del "fenomenismo individual».

4. El empeño de Mager por concordar la fenomenología psicológica de santa Teresa con la psicología racional de santo Tomás, le lleva a desviarse de sus propios propósitos (cfr. CARDEIL, A. , La Struture de l'experience mystique, 2 vols., 2 ed., París, 1929). La transformación del mundo había comenzado con los "wikingos», es decir, con la introducción de la técnica. SPENGLER, C., El hombre y la técnica, Madrid, 1934, p. 9S. San Alberto Magno acusaba el cambio: experimentum enim solum certificat. Bacón sacó las consecuencias. Por eso, hemos de lamentar que todavía no tenemos un estudio sociológico cabal de san Juan de la Cruz (cfr. BARUZI, J., saintJean de la Croix et le problème de l'experience mystique, 2 ed., Paris, 1935, p. XVIII), aunque se han publicado muchos y buenos estudios parciales. Se ha encuadrado al Santo en la Escuela Carmelitana ( $P$. Crisógono); se la ha presentado como "conquistador de insulas extrañas» (BALTHASAR, U.v. Dieu et I'homme d'aujourd'hui, Desclée, 1966, p. 212); pero falta mucho por hacer, sobre todo por liberarse de juicios inveterados.

5. Mons. Garronne proclamaba esta actualidad, al inaugurar el Congreso de Angers de 1970, sobre la "Actualidad de san Juan de la Cruz». El P. Luciano Maria, en un estudio importante, anotaba que el Patriarca Atenágoras y el doctor Ramsey tienen al místico castellano como «lectura espiritual» y base de espiritualidad.

6. Asi el Congreso de Angers se contentaba con poco, ya que nadie niega esa actualidad. También Don Andrés Gozier (Jean de la Croix. Présence dans le silence, Desclée, 1976), se contentaba con poco, al centrar la actualidad del santo en el objetivismo de la fórmula "Todo-Nada», en sus dos "planos" a saber: el de la sociedad de consumo, para la que Dios es nada y el mundo es todo, $y$ en el del realismo espiritual, para el que Dios es todo y el mundo es nada. A esos dos planes se contraponen la trascendencia de Dios, a quien no podemos definir ni nombrar, y por ende es nada, y el realismo del mundo que es el conjunto de las cosas concretas que tienen definición y nombre propio y por ende es todo. Es claro que eso puede alegarse, al hablar del místico castellano, pero no es esa quizá su mayor y específica gloria.

7. El mismo dom Gozier pregunta: ¿se trata de un «Koan Zen»? Y aunque responde negativamente, la misma pregunta anuncia una relación, que no puede ser «objetivista». De hecho, subraya el mérito del estudio de María Antonieta Raccat, (Trascendencia de Dios y relación con el mundo, Ed. del Carmelo de la Plesse, 1974) que relaciona a san Juan de la Cruz con Dietrich Bonhoeffer. Incluso añade que el estudio hubiera sido más claro, si la relación se hubiera establecido con Teilhard de Chardin, y no con Bonhoeffer. Pero es notorio que se trata de algo más, pues dom Gozier se apresura a establecer que aquí no se trata de oponer un verticalismo como re- 
del Congreso de Angers ${ }^{8}$. Damos, pues, la razón a Paliard, en sus dos libros mencionados en la nota, estimando que hoy la actualidad de san Juan deriva de su concepción profunda y de sus análisis profundos del alma humana, en su incesante choque con la trascendencia. Sin duda que nuestra época es "época de comunismo" y por todas partes se oyen los himnos de la "vida común». Pero esta "Sociedad de Consumo», que va despersonalizando al individuo poco a poco, se ve enfrentada con "tres noches» sanjuanistas, como ponía de relieve Besnard en el estudio citado. Por eso, al alma se escudriña a sí misma.

Hemos envenenado la economía, la ecología y el ecumenismo, el habitat del hombre. Se imponen pues, por un lado, la revolución real, el personalismo, y por otro lado el uregreso a sí mismo». Sólo una nueva «retirada estratégica y universal» ( $y$ a eso apuntan los hippies y grupos de espiritualidad orientalista, aun inconscientemente) nos permitirá enfrentarnos con los «demonios» que se han alojado en nuestro habitat interior. Debemos exorcizarnos, purificarnos de la posesión diabólica, mediante una noche del sentido y de una noche del espíritu.

Es verdad que hoy se nos predica el amor al mundo, la solidaridad con el mundo, puesto que somos la luz, la sal y la levadura del mismo mundo. Pero, para cumplir nuestra misión cristiana, nunca debemos confundirnos con el mundo o con una función del mundo, como con tanta frecuencia vemos. Nuestra situación es hoy paradójica, y por eso mismo, no basta que tomemos posesión de nuestra interior personalidad, sino que tenemos que participar en una "reforma», semejante a la reforma carmelitana, aun a sabiendas de que es probable que nos sobrevenga la "noche toledana». Juan de la Cruz nos enseñó a afrontar tales consecuencias.

Pero el triunfo del psicoanálisis y de la Sociología nos hacen hoy más interesantes al místico castellano. El científico actual nos presenta el Inconsciente como un pozo negro, desierto, noche, drama trágico, lucha de tensiones ciegas. No nos atrevemos a aceptarnos a nosotros mismos, y nos contentamos con normas de moral, estética, lógica, cosmología y otras «ideologias», que la mística de san Juan desnuda y desenmascara ${ }^{?}$.

acción contra el horizontalismo reinante; además, presenta como solucción de los contrastes a Cristo Mediador, que reúne la eternidad con el tiempo, según aparece en «el Cristo de san Juan de la Cruz", o en el Cristo de Dali. Todo eso está muy bien, pero demuestra que no es suficiente para explicar la actualidad fascinante de san Juan de la Cruz en el día de hoy.

8. Cfr. Lucien Marie y Jacques Marie Petit, en Actualité de Jean de la Croix, Desclée, 1970. Son las comunicaciones presentadas al Congreso mencionado. El estudio a que hemos aludido, $y$ que lleva el mismo título del libro, es de BESNARD, A. M., "Actualité de saint Jean de la Croix», ibid. p. 111-127. PALIARD, J., Profondeur de l'Ame, Paris, 1954. Id., "L'Ame de saint Jean de la, Croix et la pensée contemporaine, Tarascon. Ed. Du Carmel, 1942.

9. El psicoanálisis, a pesar de sus defectos, y a veces, a pesar de su hipocresía $y$ «mala fe", denuncia la «mala fe» de los demás, y en general, la mala fe de los hombres. Es clara la dificultad con que el psicoanálisis tropieza, sobre todo por los prejuicios en que se funda a priori. Pero hoy 


\section{Aventura perfecta}

Así califica U. v. Balthasar la gesta de san Juan ${ }^{10}$. No se trata sólo de la aventura de la santidad ${ }^{11}$, o de una retirada estratégica y metódica, con voto de pobreza absoluta y de soledad del corazón ${ }^{12}$; Balthasar trata de asimilar la gesta de san Juan a la del Dante. Claro que, al faltar las esferas y los símbolos, los Virgilios y Beatrices, los diálogos de condenados y las críticas políticas, todo se reduce a un mero título. El espíritu de san Juan es el «pathos de los Conquistadores» que exploran América, que buscan Eldorados, y ya no es el espíritu florentino, imaginario e idealista. El nuevo mensaje se intitula «acción» ${ }^{13}$. Es acción en cuanto exploración de sí mismo y en cuanto reforma de sí mismo y de los demás.

Hay que volver a recordar la conyuntura de la reforma protestante, ya que otra vez se centra la batalla sobre la Sola fides. La fe, aparte su origen sobrenatural y divino, se nos presenta en expresiones experimentales; una fe inductiva, fiduciaria. No se discute ya su origen o su carácter infuso, sino su autenticidad y seguridad psicológicas. Lo que se acentúa es la verificación subjetiva y objetiva del misterio cristiano en la persona del creyente y del místico. Parecen innegables ciertas concomitancias de san Juan con los reformadores europeos. Pero el santo se opone radicalmente al espíritu protestante, no sólo en cuanto que se atiene a la tradición o "principio de exterioridad», sino más radicalmente en cuanto armoniza la fe con la razón, Palestina con Grecia. Aunque se separa de los discípulos de Melchor Cano y rompe con la Edad Media, apropiándose el espíritu del Barroco, mantiene la vieja lealtad a la filosofía e incluso la nueva pasión de la psicología científica y experimental, que se toma como punto de partida ${ }^{14}$. iLástima que el barroco castellano, por

es imposible ignorar las "profundidades» del inconsciente. Es, pues, natural que san Juan de la Cruz se preste a estudios concienzudos sobre el alma humana. Así creemos que la actualidad de san Juan de la Cruz es por razón del alma humana y sus profundidades, postura típica de la época moderna, y no por su "objetivismo», postura típica de la antiguedad y de la Edad Media.

10. La Gloire et la Croix, Styles, II, Paris, 1972, p. 7.

11. BORD, A., Mémoire et Espérance chez saint Jean de la Croix, Paris, Beauchesne, 1971, p. 37-57. Por desgracia mía, he conocido este libro cuando ya tenía acabado mi estudio. He tenido que limitarme a añadir algunas notas. Pero me produjo gran satisfacción ver que alguien se fijara en la importancia de la memoria para el místico castellano, y que se asombra del silencio en que se ha mantenido este tema.

12. S. AGUSTIN, Noli foras ore, in teipsum redi... De Vera Religione, 39, 72 PL 34,134. DESCARTES, Duda metódica; HUSSERL, Meditations Cartesiennes, etc.

13. «El mar ya no es el mar del A.T., sino el mar tenebroso de Colón, por el que se va a una conquista, por caminos nunca sabidos.... Es el pathos del descubrimiento del mundo, en el tiempo de los conquistadores» (U. v. BALTHASAR, I.c., p. 14ss). Esto implica "embarcarse» y posiblemente "quemar las naves", $y$ finalmente un riesgo total. Se exige, pues, la renuncia total al espiritu de propiedad, un camino de nada para llegar al Todo" (Cfr. SANSON H., L'esprit humain selon saint Jean de la Croix, Alger, P.U.F., 1953, p. 49). Es pues «la aventura perfecta».

14. PRZYWARA, E., Augustinus, Leipzig, 1934, p. 42s.- BALTHASAR, I.c. MOREL, G., Le sens de l'existence selon saint Jean de la Croix, 2 vols., Paris, 1960, en un sentido neohege- 
su condicionamiento sociológico, no se mantuviese a la altura en que le colocaba la mística carmelitana!

La tensión entre eremitismo y apostolado estaba ya resuelta a favor de la acción y de la reforma. La contemplación misma se convertía en instrumento de acción, y en eso insistían san Juan y sus discípulos carmelitas. Ninguna teología negativa, ningún molinosismo o ningún quietismo podrían justificar la indiferencia, el dismulo o la "caída» en la carrera de la acción. Duruelo y el Desierto de Beas, con todas sus calaveras y cruces de palo, eran focos de irradiación apostólica. Es cierto que, al hablar tanto de la noche y de la nada, se corría el riesgo de convertir el mundo de los valores en trasparencia y alegoría, al modo neohegeliano. Pero precisamente Balthasar afirma que la postura de san Juan en ese tiempo y lugar era «un escándalo y una provocación»: no sólo protestaba contra cierta autonomía del mundo, sino que al mismo tiempo la exaltaba ${ }^{15}$.

\section{La personalidad}

Sin duda poseía san Juan una extraordinaria personalidad ${ }^{16}$. Parece objetivista y es subjetivista; parece tradicionalista y es un aventurero; no habla de sí mismo, y en cada página se retrata; parece imitable y no hay quien le imite; su verso parece académico y es volandero; parece un castellano viejo, y es un hombre nuevo. Allison le llama "castizo" y lo es en más de un sentido. La «noche toledana mostró que no era hombre fácil de doblegar o domesticar. Aunque estrechemos sus lazos espirituales con los de santa Teresa, nunca podremos confundirle con un Gracián y menos con un Doria. Le aplicaríamos la fórmula bíblica: «puso nombre a todos los ganados, a las aves del cielo y a todos los animales del campo; mas para él no hubo una ayuda semejante a él» (Ge 2,20).

Ese Solus cum Sólo de los neoplatónicos nos plantea una nueva paradoja: todas las personas son incomunicables, pero todas tienen una raíz común. Y suele acontecer que cuando una personalidad es más destacada, más enraizada es también. La profundidad y altura de cada personalidad suele depender de su grado de penetración en el fondo común. En el caso de san Juan de la Cruz eso parece comprobado.

liano. Asi se comprenden mejor las coincidencias de fondo y las diferencias de modo entre san Juan y Pascal (Cfr. BALTHASAR I.c.). En efecto, estaban ya en un mundo nuevo, y era preciso aceptar la aventura perfecta, en lugar de envolverse en un quijotismo. La experiencia de Lutero y Descartes no era un mera casualidad, ni un problema secundario.

15. BALTHASAR I.c.; MOREL, I.c. La tradición de las Ordenes Medicantes suprimía de raíz el peligro de eremitismo o de quietismo. Teresa de Jesús no había suprimido los «locutorios», sino que los había transformado. Los que exageran el quietismo sanjuanista, lo hacen por caer en especulaciones abstractas y aristotélicas. En todo caso, la tradición de los discípulos de san Juan muestra que en realidad nunca hubo peligro de quietismo.

16. ALLISSON PEERS., Spirit of Flame, 4 ed., London, 1944, p. 81-93. 
El fondo común o trastienda está situado en lo que solemos llamar el inconsciente, que los antiguos llamaban «sustancia del alma». La separación entre la zona consciente e inconsciente del alma no es rígida ni total. Puede un alma llegar a purificar y unificar tanto su interior, que prácticamente quede borrada la frontera entre el consciente y el inconsciente, de manera que el inconsciente (que constituye la parte mayor y más «natural» del alma) asuma y dirija la totalidad del ser humano. En ese caso, el sujeto se ve dirigido como por un «instinto racional», por la naturaleza radical, y no ya por ideologías convencionales, tales como las que nos enseñan la moral, la estética, la lógica, etc. La naturaleza heredada se sobrepone entonces a la naturaleza adquirida y convencional, o comercial. Una nueva experiencia personal se sobrepone a la experiencia adquirida a lo largo de la existencia en la «sociedad de consumo». En cuyo caso el místico tendrá una suerte de consciencia refleja de su "pasividad» ya que esa pasividad es caracteristica de todos los fenómenos del inconsciente. Por eso dirá san Juan que no utiliza "las potencias del alma»; obra por lo que sabe y no por lo que le hayan enseñado.

Así aparece la objetividad interior, la deidad objetiva y subjetiva del místico, unida a su propia personalidad. Hablará del fuego que pone al rojo el hierro, y del madero húmedo que se transforma en fuego. Tal «entelequia» humana es la deificación, el supremo y radical sueño humano, el hombre trascendido en superhombre. Tal es el misterio personal de la memoria de Dios (san Agustín) o del enraizamiento horizontal y vertical (Simone Weil) ${ }^{17}$.

\section{Estética y mística}

Si consideramos la religión radical como super valor, los demás valores corrientes (el estético, lógico, ético, jurídico, ontológico, y aun el político y el económicol son ya formas determinadas del profundo valor religioso. Puede haber, pues, una forma abusiva de subordinación de un valor a otro, puesto que todos son irreductibles. Pero puede darse una forma correcta de subordinación, que no es "reducción», sino que mantiene la independencia correlativa. Y eso se advierte bien en san Juan como en Lutero.

Según san Agustín, la poesía es una hija de la mística ${ }^{18}$, hija también de Júpiter y de la memoria, es decir, de la inspiración y de la técnica. En los car-

17. WEIL, Simone, L'Enracinement, Gallimard, Paris, 1949. «El enraizamiento es quizá la necesidad más importante y más desconocida del alma humana». No se trata sólo de un enraizamiento horizontal, sino también vertical, en profundidad. Cfr. GOZIER, A., Présence dans le silence, Paris, Desclée, 1976. DELAYE, La Foi, selon saint Jean de la Croix, Carmel, la Plesse, . 1975; GUILLET, L., Ce que croyait saint Jean de la Croix, Mame, 1976: KELLY NENNECX, Fr. Teilhard de Chardin et Jean de la Croix, Desclée 1975.

18. S. Agustín, De Ordine, II, 14,39 PL 32,1013. Según esta teoría, la poética es parte integrante de la mística general. Tanto la mística como la poética son "grados» o escalones para la contemplación de la Belleza, deseada a priori, y por ende conocida a priori. 
melos de Teresa reinaba el entusiasmo, en el sentido etimológico y originario de la palabra. Eran comunidades de "convertidos» o renacidos, y a ellos pertenecen la exaltación y la agaliasis de los primeros cristianos. Si, como dice san Agustín, uel cantar es oficio de enamorados», en aquellos carmelos la poesía era religiosa y la religión era poética. Pero eso reclamaba ciertas costumbres, o sea, una técnica. Juan de la Cruz debió escribir versos para cantarlos (motetes, letrillas, tonadas) como se comprueba en la repetición del «véante mis ojos». Cuando nos cuentan que Teresa hizo cantar a una religiosa el «véante mis ojos» para regalar a Juan, y éste cayó en éxtasis, no sólo se describe una "florecilla», sino también un ambiente y una ley ${ }^{19}$.

Sin embargo, la circunstancia sola no podría explicarnos esa íntima unión de la poesía con la mística en san Juan. Parece claro que Juan rompió a cantar místicamente en la «noche toledana». En aquel calabozo negro y en las altas horas de la noche de insomnio, la poesía y la religión eran para el santo la misma cosa en él, aunque fueran diferentes en sí mismas. Su alma flotaba en absoluta soledad, entre el cielo y la tierra, sin pertenecer ya al uno ni a la otra, como crucificada. El alma se enfrentaba con la trascendencia, con Dios, como un abismo que invoca a otros abismos (san Agustín). Aunque la poesía fuera aquella noche una evasión de la religión negra y doliente; aunque fuera el impulso enamorado de una aspiración mística; aunque fuera idealismo quijotesco; en cualquier hipótesis, la poesía o poema de san Juan de la Cruz sólo puede producirse en un "trance», es decir en una "situación inspirada», que reconocen fácilmente los que viven una profunda vida interior: es emoción profunda que se desborda. Los modernos poetas, que han exaltado tanto a san Juan, descubren en él excelentes «profundidad y calidad»; pero hay que decir que en la sencillez y pobreza del verso podría darse el mismo encanto inspirado. Podríamos desnudar el poema de todo artificio y nos estremecería la intuición elemental: el alma sale de noche, cierra con llave la puerta de la casa, y mira al cielo, suspirando.

Resulta excesivo que los versos del místico castellano están escritos en estado "teopático». Revelan un oficio, una técnica, unas fuentes. Bastará, pues, reconocer esa soledad del corazón, que conocen los enamorados y que es, como decíamos, crucifixión entre el cielo y la tierra. La lira marca un paso rítmico y monótono, que resuena en la noche, como un tambor en la profundidad del bosque encantado ${ }^{20}$.

19. FLORISOONE, M., Esthétique et mystique d'aprés Ste. Thérèse et saint Jean de la Croix, Paris, 1956. Además de tratar muy bien el tema, responde a los críticos, que creen ver en el santo un espiritu seco y heroicista. Cfr. ALONSO. D., La poesía de san Juan de la Cruz, Madrid 1942; MONCHANIN, J., De l'esthetique a la mystique, Caterman 1967.

20. SAN AGUSTIN: Laboro hic et laboro in meipso: factus sum mihi terra difficultatis et sudoris nimii. Confess. X, 16,25 PL 32,789). Cfr. PELLĖ-DUEL, Y., Saint Juan de la Croix et la nuit mystique, Paris, 1960; PEPIN, F. Noces de feu, Paris, 1972: RACCAT, A. M., Trascendance de Dieu et relation au monde, Jean de la Croix et Dietrich Bonhoeffer, Carmel, La Plesse, 1974. 


\section{La revelación de la estética}

Todos los autores reconocen el quid divinum de los versos Sanjuanistas, en comparación con la prosa, aun siendo ésta también muy buena. Pero quizá nos quedemos cortos al hablar genéricamente de una inspiración y de una técnica. Milner y Baruzi consideran, con razón, que tales versos son uresonancias reflexivas», reminiscencias, fichas de una concreta situación, que se recuerdan con viveza, y que podemos llamar «visión» ${ }^{21}$. Son la música y la letra que evocan la visión sensorial, imaginaria o intelectual. De ese modo nos encontramos ante una paradoja: san Juan rechaza o margina las visiones concretas, pero luego las refleja con tal energía, con un colorido y realismo $\tan$ vivos y palpitantes, que nos subyuga. No nos basta recurrir a las fuentes. No basta consultar el Cantar de los Cantares para explicar un verso tan intuitivo, sintético y alucinante con éste: "Quedéme y olvidéme, el rostro recliné sobre el Amado, cesó todo y dejéme, dejando mi cuidado, entre las azucenas olvidado». Cierto, el Cantar de los Cantares es evocado pero tan libremente y con tal acento, pasividad y pasión, que nadie podría adivinarlo ${ }^{22}$.

Por eso dice muy bien Bathasar que el santo vivía obsesionado por la belleza, no sólo por la sobrenatural, sino también por la natural y sensible, continuando su perpetua paradoja: su sensibilidad no se somete a las normas teorizantes. Así lo revela su verso y también su prosa y así lo recuerdan los testigos que le acompañaron en sus caminos de la tierra ${ }^{23}$. La Noche de que tanto nos habla, es un símbolo, es decir una palpitante realidad, aunque además sea una referencia a Dios. Esa noche no es mera negatividad, ausencia del día y de la luz, sino que es la propia vida interior, y como tal es para él mismo "tierra de sudor y de congoja», pero al mismo tiempo, atractiva y fascinante (san Agustín). La noche del alma es el espejo y enigma de Dios, la ima-

21. MILNER, M., Poésie et mystique chez saint Jean de la Croix., Paris, 1951; BARUZI, I.c.; BENZ, E., Die Vision. Erfahrungsformen und Bilderwelt, Stuttgart, 1969. MONCHANIN, I.c., exagera afirmando que san Juan convierte el símbolo en alegoría. Más ponderado y matizado es U.v.BALTASAR, I.c. Cfr. CHERING, E., Mystik und Tat. THerese u. J. vom Kreuz und die Selbsbehauptung, München, 19597. Exagera también, al oponer Teresa, tipo «eidético» a Juan, tipo «no eidético»: lo dicho sobre el verso sanjuanista es una refutación: Juan refleja visiones tan concretas como las de Teresa.

22. LERCH, D., "Zur Geschichte der Auslegung des Hohenliedes», en Zeits. f. Theol. $u$. Kirche., (1957) 257 ss. BALTHÄSAR, l. c. p. 50. Por consiguiente, la Noche es símbolo y no alegorla, tanto en S. Juan de la Cruz como en Fr. Luis de León. Es un símbolo apropiado y magnifico de Dios.

23. SALINAS, P., Reality and the Poet in Spanish Poetry, Baltimore; 140, p 123. Establece una diferencia exagerada y caprichosa entre ambos poetas castellanos; hay, sí, una diferencia, pero se debe a que san Juan deja obrar a su inconsciente, y no a la Academia, como Fr. Luis. Cfr. MA JOIE TERRESTRE, OU EST-TU? (Etudes Carmelitaines, Desclée, 1947). Siempre hubo tendencias al intuicionismo, a dejar operar al insconsciente. El surrealismo convirtió tales tendencias en teorías y sistemas. Las drogas actuales y tratamientos de "éxtasis» y «mística de Nescafé» insisten. Lo difícil es ordenar el inconsciente. 
gen tenebrosa de Dios. La noche estrellada habla de Dios mejor que todos los jardines iluminados por el sol. Eso mismo les aconteció a Fr. Luis y a otros ancarcelados, que supieron por experiencia lo que es "la noche toledana».

La circunstancia sociológica corrobora ese sentido de la noche. Balthasar nos hace notar que los tres apoyos del poeta místico, el teológico-bíblico, el humanista y el grafismo musical de los cancioneros castellanos, colocan el Cantar de los Cantares en Castilla, en un tiempo en que los exploradores castellanos, o al servicio de Castilla, recorrían las selvas americanas en busca de El dorado. San Juan de la Cruz es el símbolo ejemplar del alma castellana que bucea dentro de sí misma, o se explora a sí misma, buscando los vestigios y huellas de Dios, para ir a él. Pero, en esa exploración, el alma castellana se da cuenta de que se ha interiorizado tanto que se ha trascendido: Tenía dos fachadas, una hacia el exterior y otra hacia el interior, hacia Dios. La trascendencia era ya la frontera interior de la objetividad divina. En el interior del alma, en el inconsciente, surge un continente iluminado por la aurora boreal. San Juan queda, pues, aprisionado en la mística, en la belleza inevitable, rehaciendo la fórmula teresiana: «que no me puedo valer».

\section{La relación con el mundo}

P. Salinas presenta a Juan como ejemplo de escape de la realidad circundante hacia la realidad interior: crea, dice Salinas, un espacio vacío para contemplar las cosas a la conveniente distancia; describe magnificamente el ufenómeno", pero luego se refugia en su conciencia; la noche es ese espacio vacío en que se produce la unidad poética absoluta. La diferencia con Fr. Luis de León consistiría en que éste admite mediaciones y san Juan no las admite ${ }^{24}$. Es una exageración en sus dos partes.

U.v. Balthasar ${ }^{25}$ asimila la postura de san Juan a la cognitio matutina, de san Agustín, por lo menos en cuanto al espíritu. En su ida hacia Dios Juan renuncia a todo, pero luego lo recupera todo desde Dios. Ve las cosas saliendo de Dios, tales como las ve y las ama Dios ${ }^{26}$. Ahora bien, descubrir lo que pri-

24. Salinas, I.c.

25. BALTHASAR, I.c. San Agustín, De Genesi ad litt. IV, 24,41 PL 34, 313. El mismo san Agustín nos coloca en un contexto muy diferente, pues lo que pretende explicar es: posibilidad para los ángeles (y quizá para los hombres) de contemplar la eternidad del Creador; 2) los ángeles son conscientes de la mutabilidad de las criaturas; 3) este conocimiento inferior contribuye a la gloria del Creador, (Cfr. Ibid. IV, 29,46 col. 315). El otro tipo de conocimiento en Confessiones XIII, 31,46 PL 32,865. Cfr. De Ordine, I, 8,25s PL 32,989. Según esa referencia a la anamnesia platónica dice san Juan: "Y este es el deleite grande de este recuerdo, que es como un despertar». $Y$ añade: "Conoce por Dios las criaturas y no por las criaturas a Dios; que es conocer los efectos por su causa y no la causa por los efectos, que es conocimiento postrero (trasero), y este otro es esencial) (Llama IV ,2) MOREL toma este pasaje como punto de partida, sin advertir que todo depende de la interpretación que se le de. (MOREL, l.c., p. 347).

26. Sobre el conocimiento mistico Cfr. ALBRECHT, C., Das mystische Erkennen, Bremen, 
mero renunció es redescubrir. Por ende, san Juan es un obsesionado de la belleza sobrenatural y natural: sus metáforas y descripciones no son alegorías o figuras literarias, sino símbolos, experiencias y gritos, como en el caso de Fr. Luis de León. Florisoone ha desvanecido todas las inexactitudes que suelen aducirse sobre el espíritu sombrío y goyesco de san Juan ${ }^{27}$.

Ahora bien, san Agustín presenta dos tipos de cognitio matutina. La primera la presenta en el De Genesi ad litteram: es demasiado técnica y artificiosa, demasiado ligada a la tradición griega. Aunque Balthasar parece referirse a ella, creemos que ese caso es también una exageración. Pero hay en las Confesiones otro tipo más personal y agustiniano de cognitio matutina: Dios ve las cosas con nuestros propios ojos, y nosotros vemos las cosas como con un ojo divino ${ }^{28}$. Cuando vemos las cosas como creadas por Dios, como criaturas, vemos su ideal, vemos a Dios en ellas. Cuando ellas nos agradan, nos agrada Dios en ellas, como si se tratase de un Museo de Dios. Estamos lejos, no sólo de las «ascensiones» platónicas y medievales, «por la escala de las criaturas», sino también de las "ascensiones por las potencias del alma», a la manera agustiniana. El espíritu humano sabe que él mismo es la frontera de Dios, y que el Dios-Valor (Verdad, Bondad, Belleza, Ideal, etc.), mora en su interior como "objetividad subjetiva», comó Deus in nobis, salvada la diferencia entre creación y emanación con los neoplatónicos. El poeta dirá «entusiasmado»: «Mil gracias derramando, pasó... » y también: «los ojos deseados -que llevo en mis entrañas dibujados...» Cada objeto es un objeto, un símbolo, no una alegoría, no una trasparencia de Dios, no una vidriera sucia. Pero cada objectum es referencia, llamada, signum, visum...

\section{Filosofía y mística}

Los críticos descubren en san Juan una filosofía subyacente. Sería muy útil poderle inscribir en algún determinado sistema, para poder llenar las lagunas y conjeturas posibles. Pero eso no es fácil. En general es aristotélico y tomista, pero con independencia de criterio y sin carácter técnico. Mucho le ha perjudicado nuestro empeño de hacerle "tomista» oficial: así se le pone en continua contradición consigo mismo, ya que su experiencia es una refutación del tomismo aristotélico. Por otro lado, se quejan después los tomistas de que el santo no utiliza un lenguaje técnico, de que acusa influencias nominalistas, y aun árabes (como John de Baconthorp), de que se deja arrastrar por la independencia de criterio de sus profesores de Salamanca, y finalmente

1958: KAR̃RER, O., Gott in uns. Die Mystik der Neuzeit, München, 1926. RECEJAC, E., Essai sur les fondements de la connaissance mystique, Paris, 1897. CRISOGONO de Jesús, La Escuela Carmelitana, Avila, 1930, p. 80ss.

27. No aceptamos la interpretación de Krynen en Religión y Cultura, 22, (1976) 465.

28. SCHELER, M., Ordo Amoris, Madrid, 1934, p. 123. 
de que es un «psicologista», que después quiere justificarse con una tradición bíblica, patrística y escolástica. La culpa es de los mismos tomistas que parten de un falso supuesto, y pretenden crear oposición entre psicologismo y metafísica, cuando la oposición está entre formalismo abstracto y personalismo cristiano y moderno. Tomar como norma la uortodoxia» tomista para enjuiciar a Juan es condenarle de antemano a ser un mal discípulo, es entregarle a la Inquisición.

Es también un error encuadrar a Juan en una tradición bíblica, patrística o escolástica. Aunque el mundo «moderno» significaba en algunos aspectos, una "vuelta a la Biblia», en otros aspectos era un mundo nuevo, muy diferente del bíblico y exigía visión muy diferente. Los Padres, tanto orientales como occidentales, vivieron en una época de metafísica helenística, en especial de platonismo. Mager, Stolz y los "orientalistas», condenan luego a san Juan por psicologista e incorregible subjetivista. Compararle con san Agustín es muy posible, sobre todo en sentido genérico; pero se trata de dos casos demasiado únicos y personales: la mística de ambos es muy diferente, ya que san Agustín renunció formalmente a la mística de visión, para refugiarse en la mística de Cristo de tipo teológico, como la mística paulina. En cuanto a la escolástica, es aristotélica incluso en el "agustinismo», pues las definiciones se toman de Aristóteles; pero esa filosofía es condenada de golpe con la llegada del mundo moderno, como hemos visto. El místico castellano apunta ya al futuro, a la modernidad: el subjetivismo y psicologismo (personalismo) que se denuncian como defectos, son un gran progreso ${ }^{29}$.

\section{En la frontera}

San Juan acepta de lleno la armonía entre la fe y la razón. No necesita plantear formalmente el problema, ya que nadie entenderá sus paradojas, si no conoce el legado cultural de los místicos. Aunque se han hecho tentativas para compararle con varios otros personajes históricos, y aunque hemos dicho que él y san Agustín son dos "casos únicos» excesivamente personales, quizá es riecesario remontarse a san Agustín como fuente de una larga tradición para entender bien a Juan. No sólo porque así se entenderían mejor las dos fórmulas correlativas crede ut intelligas e intellige ut credạs, sino también porque el cristianismo aparece como la ureligión verdadera», es decir, como la

29. Es una pena que aún no conozcamos debıdamente las fuentes de nuestros místicos en su relación con los Neoplatónicos. En conjunto vemos que la relación es profunda y extensa, como puede comprobarse en Fr. Luis de León, Malón de Chaide, Bto. Orozco, etc. En ningún caso y en ninguna hipótesis pretendió san Juan, como afirma Krynen, eliminar la filosofía de los antiguos en nombre de la fe, como si fuese un luterano: su exploración del hombre hastą descubrir a Dios es admirable y digna de su tiempo. Cfr. ALQUIĖ, F., La découverte métaphysique de l'homme chez Descartes, Paris, 1950. 
religión esencial en la que todas las religiones positivas caben y desembocan. Queda, pues, eliminada toda pretensión de convertir a Juan en un «tomista» o en un "evangelista».

Eso supone que trabajamos a mucha profundidad. Tanto el Fenomenismo, como el logicismo advierten que, para sostener los fenómenos y las leyes mentales, es necesario otro mundo esencial, sustancial, objetivo, que se revela en una antropología metafísica. La distinción real entre la sustancia (que no es inmediatamente operativa) y las potencias se convierte en caballo de batalla. Juan opone la sustancia a los accidentes y potencias; pero no da las oportunas definiciones, y se envuelve en su experiencia y en su misterio: "Dios produce en la sustancia del alma palabras no determinadas, sino sustanciales», etc.) Un "toque de Dios» inflama la sustancia del alma sin tocar las potencias: parece un toque panteísta de esencia a esencia, y por eso los críticos dicen "de persona a persona», por escrúpulo. Pero lo cierto es que las "potencias» tienen que penetrar por necesidad absoluta en la sustancia del alma o pertenecer a ella.

Volvemos a san Agustín, como a la fuente. En Agustín, la sustancia del alma viene a coincidir con el corazón, con la memoria metafísica, con lo que hoy llamamos el inconsciente. Las potencias son en parte conscientes y en su mayor parte inconscientes; así admiten dos lenguajes distintos, el relativo y el absoluto. En este sentido, podemos ya decir muy bien «persona» en lugar de "sustantivo». La sustancia del alma es el inconsciente y por lo mismo la sustancia trabaja con potencias «suștanciales», aunque el hombre no lo advierte. No basta, pues, ni el Cogito ni la Sindéresis; es necesario el inconsciente, la sustancia, como soporte metafísico de ambos ${ }^{30}$.

\section{Teología y mística}

Puesto que corresponde a la Teología precisar la "ortodoxia», como criterio externo de la mística, presentemos la doctrina de santo Tomás como

30. Como veremos a continuación, la discusión central surge en la distinción entre la sustancia del alma y sus potencias, es decir, en una antropología fundamental. Se recurre con frecuencia a las fuenı̀es, en especial a Laredo; se explica la postura de san Juan como «distinción virtual entre la sustancia y las potencias del alman, para enlazar con los renanos. Lo malo de esa fórmula es que recae en un viejo e insoluble problema, que modernamente ha sido indebidamente justificado por un estudio profundo, pero mal orientado, de M. SCHMAUS., Die psychologische Trinitätslehre des HI. Augustinus, Munster, 1967. Schmaus somete a san Agustín al sistema aristotélico y así lo deforma desde el principio; pero por las apariencias científicas de su libro es incalculable el daño que ha producido. Sea lo que quiera sobre la «distinción virtual» en san Agustín. es cierto que en la Edad Media esa sentencia fue mantenida bajo auspicios aristotélicos. Es pues muy posible que san Juan hubiese tomado esa teoría de la distinción virtual de Taulero; pero eso habría que demostrarlo rigurosamente. Cfr. OSCIBAL, J., saint Jean de la Croix et les mystiques flamands, Desclée, 1966. 
punto de partida e inteligencia ${ }^{31}$. Al principio el Angélico admitía fácilmente la doctrina de la escuela de san Víctor; pero en la Suma se mostró muy reservado. Se ha optado, pues, por ver qué opinaba sobre la «contemplación de Adán», pues dice que es intermedia entre la visión beatífica y la que se logra por el entendimiento agente. Adán veía a Dios gracias a una luz sapiencial, o mediación. Tal luz admite grados (los santos, los profetas, místicos, hagiógrafos, Moisés, san Pablo), pero conserva siempre su carácter de lumen gratiae. El Angel ve a Dios por naturaleza, Adán le veía por gracia, lo mismo que lo ven los místicos, mutatis mutandis. La mística acepta esos límites en la teoría y en la experiencia práctica ${ }^{32}$.

Dios no puede ser causa material ni formal de la criatura: es pues necesario recurrir a una "mediación» o forma creada, que es la gracia, para unir al hombre con Dios ${ }^{33}$. Mediante esa gracia creada, produce Dios en el alma una imagen de sí (asimilación, semejanza); atrae al alma hacia sí (finalización); obra en el alma como causa ejemplar. $Y$ esto es lo que llamamos «unión». $Y$ ya que la gracia es el principio de las virtudes $y$ de los dones sobrenaturales sólo podemos unirnos a Dios por el conocimiento y el amor, jamás por la unión o confusión de sustancias. Es verdad que a la «unión por participación» la llamamos a veces «unión sustancial», pero sólo queremos decir «unión de semejanza». De ella deriva las otras tres formas de unión: pasión, operación, y finalización o asimilación. Dios conserva en el alma la gracia y concurre a sus operaciones, y así la eleva al orden sobrenatural (pasión); en cuanto causa ejemplar, produce un efecto semejante a él (asimilación); finalmente en cuanto causa formal externa, se constituye en objeto de fe $y$ amor, y con estos el alma alcanza a Dios. No hay, pues, ningún otro principio formal de unión, fuera de esa gracia ${ }^{34}$. En suma, el elemento específico de la unión de gracia es la "unión de operación», intermedia entre la unión hipostática o la unión de la visión beatífica y la unión natural de la criatura con su creador: sólo tocamos a Dios con nuestra operación ${ }^{35}$. Pero todo esto es teología, no mística.

31. ROY, L., Lumière et sagesse. La grâce mystique dans la Theologie de St. Thomas d'Aquin, Montreal, 1948, p. 280.

32. MORENOY, R., L'Unión de gracê selón S. Thomas, Montreal, 1950, p. 246s; GARRIGQU-LAGRANGE Perfection chrétienne et Contemplation selon $S$. Thomas d'Aquin et $S$. Jean de la Croix, 2 vols., 6 ed., S.Maxim, (1Ed. 1923); STOLZ, A., Teologia de la Mystica, 2 ed., Madrid, 1952, p. 119. Mager reprocha a santo Tomás el no haber precisado el contenido formal de la mística: MAGER, A., "Der hl.Thomas und die mystik», en Theologie und Gleaube (1921). Lo contradice Stolz, en el lugar citado, pero sin convencer. En general se habla de experiencias o vivencias experimentales de Dios; pero se añade que no son "psicológicaș», sino "suprapersonales», lo que es ininteligible.

33. S. Th., 1, 3,8, c. Esto se aplica también al orden de la acción. La acción de un santo se debe a su voluntad, pero también al Espíritu Santo, o a la caridad procedente de la gracia. Si alguna vez decimos que Dios es la vida o la forma del alma, nos referimos a la causa formal externa, o causa ejemplar.

34. C. Gentes, 1. IV, c. 21,8.

35. Lo mismo se dirá de la «pasividad», cuando Dios toca al alma. No hay pues «toque aris- 
Juan de la Cruz no dió nunca muestras de apartarse de ese criterio externo de la ortodoxia, pero ponía su ahínco en explicar la experiencia mística, con libertad de interpretación ${ }^{36}$.

\section{Mística moderna}

Sentimos la tentación de comparar a san Juan con los autores del libro de Job y del Eclesiastés: no veían aún una solución satisfactoria, pero ya veían que las explicaciones dadas eran insuficientes, y que había que saltar afuera del callejón sin salida. De ese modo, su doctrina es una mezcla reveladora de la insuficiencia de las tradiciones y de la necesidad de ampliar los cuadros. Por eso, muchas de las discusiones en torno a san Juan son inútiles o imposibles de resolver, ya que se apoyan en "documentos», cuando lo que interesa es más bien «lo que no se dice», lo que se deja adivinar. Cuando, por ejemplo, A. Bord se pregunta si san Juan es "agustiniano o tomista» responderíamos: 1) esa alternativa es inadecuada: puede ser las dos cosas, o ninguna de ellas, o una tercera; 2) sería inútil escoger una alternativa, pues el crítico se apresuraría a tomar la respuesta en sentido «técnico», deformando así, o falseando, lo que pudiera tener de verdad; 3) lo importante es saber si lo que quiere decir san Juan es que ni el tomismo ni el agustinismo son capaces ya de explicar la experiencia de los místicos ${ }^{37}$.

totëlico». Por eso los tomistas se mantienen en general en teología. Juan de Sto. Tomás, impresionado por la «experiencia», trató de arrojar un puente de unión, desarrollando la doctrina de los «dones del Espíritu Santo»; pero creó problemas insolubles.

36. Juan de la Cruz coloca el tema de la Unión en medio del tema de la Noche (Subida, II,4), realizada ya la trascendencia (ibid). Tenemos primero la «unión del Creador con sus criaturas»; después, la "unión sustancial», que es «unión de semejanza y amor» (lbid. II, 5,2). También los «hábitos» se conforman a esta unión de semejanza. ¿Cómo pasamos de lo inconsciente a lo consciente? No se ve con claridad la solución. El P. Crisógono estima que el santo recurría a los «dones del Espíritu Santo», como Juan de Sto. Tomás (CRISOGONO, La Escuela...), pero eso es demasiado discutible y el mismo autor vacila, al citar testigos. Nadie duda de que san Juan acepta los esquemas tradicionales en forma convencional, pero es casi imposible aplicarlos. Por ejemplo, BALTHASAR, I.c., estima que la relación entre sustancia y potencias tiene que reducirse a una "relación creadora» o "dependencia ontológica de la criatura», lo que significa salirse de la mística. ¿Cómo aplicar entonces el término «sustancial» a vocablos como unión, transformación, comunicación, toque, inteligencia, palabra, sentimiento, delicia, tiniebla, etc.? ¿O cómo pasar del orden esencial al existencial? Por eso BARUZI reprocha al santo el haber admitido la relación de sustancia y potencias (Baruzi, l.c., zp. 457 y 556). A. BORD, estima que a pesar de la nomenclatura convencional, el santo es "agustiniano» (BORT, I.c., p. 73), porque enlaza con lo renanos. BORD penetra en el fondo sanjuanista, pero olvida la distinción agustiniana de lenguaje absoluto y relativo, a las potencias en cuanto son relativas y en cuanto son sustanciales. Así no logra ver la auténtica naturaleza de la memoria, ni el sentido de la «teología negativa» de san Juan, ni la condición experimental de la fe: «siendo verdad, como lo es, que a Dios el alma antes le ha de ir conociendo por lo que no es... ha de negar hasta lo último...l.

37. BORD I.c., p. 300. Alberto de la Virgen del Carmen, "Naturaleza de la memoria espiri- 
Para comprobar la insuficiencia de los textos y la necesidad de la adivinanza, basta que relacionemos, al modo sanjuanista, las potencias del alma con las virtudes teologales, infusas, inconscientes. Resulta que la memoria se relaciona con la esperanza, es decir, con el futuro y no con el pasado: es memoria de futuro. Además, si las virtudes son infusas, serán «sustanciales», «no potenciales». Pues ¿cómo los «toques» son conscientes e inconcientes al mismo tiempo? Si eliminamos todo el contenido del entendimiento, $y$ sustituimos éste por la fe, tenemos nominalismo, luteranismo y kantismo ${ }^{38}$.

Algunos críticos imitan a san Juan, cuando acosados, pretenden refugiarse en la Biblia; pero no dejan discutir histórica y críticamente los textos de la Biblia, sino que imponen su explicación, es decir, afirman que la Biblia son ellos, y su palabra es palabra de Dios. Tampoco eso es serio. Si la fe ha de ser la solución, hay que tomar precauciones para que no sea eliminada por opiniones humanas. ¿Dice la fe que en este mundo podemos ver a Dios directa e inmediatamente? Algunos dicen que el mismo santo Tomás dudó y añaden que san Juan es el campeón de esa posibilidad ${ }^{39}$. Otros lo niegan y otros advierten, que cuando el santo lo admitiera, se contradiría a sí mismo.

Vivimos en régimen de fe, no de visión, y la fe no es un ver. Es pues inútil repetir totum non totaliter o «experiencia de la gracia». Sólo por especial revelación in casu podría plantearse el problema.

tual según san Juan de la Cruzi), en Rév. de Espiritualidad, 44 (1952) 29-299. Tiene razón el P. Alberto, $y$ no podemos negar la autenticidad o sentido de los textos, desde luego. Pero el problema es si con ello podemos explicarnos los "toques» y «uniones» sustanciales, o si la fe es suficiente para «demostrarnos» la explicación. Las tesis planteadas por teólogos, al modo teológico, sirven para la teología, pero no para la mística, cuyos problemas son diferentes, y no se demuestran con textos más o menos bíblicos, más o menos revelados. Sin duda son muy útiles los estudios acerca de la memoria Sanjuanista «según los textos» (BORD, I.c., p. 306-315). Pero, por lo menos para mí, el problema revelador es esa «sustancia» tan extraña de que nos habla san Juan, y que nos obliga a sudar. Por eso BORD nos convence mucho más cuando habla con libertad, como a contece en la solapa posterior de su libro, que dice textual y magnificamente: «Este estudio, establecido sobre textos definitivamente restituidos en su autenticidad, revela una visión que anuncia, todavía mejor que la del mismo Agustín, la psicología moderna: el recuerdo como pensamiento, el recuerdo como haber personal... El propósito del autor es atenerse a un punto particular, importante, caracteristico, marginado increiblemente".

38. BALTHASAR, I.c. piensa que es necesario cambiar el concepto de fe, haciéndola mystagógica, no filosófica. Quizá es más fácil cambiar el concepto de «potencia». La fe mystagógica no nos saca de apuros... Tampoco nos saca de apuros el recurso al "amor», ya que ese amor volverá a ser "aristotélico», propio de una voluntad, realmente distinta del alma, etc. BALTHASAR recurre a otro expediente, igualmente inútil, distinguiendo entre "conquistar» y "hacerse conquistar". ¿Qué significa hacerse conquistar, obligar a alguien a que nos conquiste? Sería el | (uhiéreme»! del profeta (I Reg. 20, 35-43). Hacerse conquistar es conquistar, es demasiado. Aún discutiriamos el «dejarse conquistar». BALTHASAR se explica diciendo que en el fondo las virtudes teologales se identifican (en Dios, no en el objeto formal) y sólo se distinguen precisamente por su relación con las potencias. Pero eso es una broma, si resulta que las potencias sólo se distinguen virtualmente, como dijimos. Por ende, el problema no tiene solución ni en Dios (en sí), ni en el objeto formal, sino en el sujeto, en la experiencia misma del místico.

- 39. Para explicar la deificación, los místicos recurren a la metáfora del fuego que enrojece 


\section{La deificación}

La mística crítica surgió, al abrirse el chorismós platónico entre el mundo ideal y el real. La mística trata de restablecer la unión perdida, mediante una visión, que es unión noética con Dios. El cristianismo helenizado busca así en la "gracia divina» un arché de deificación, que puede tener sentido teológico o sentido místico ${ }^{40}$. Pero busca además sustituir la «visión de Dios» de los platónicos por una «visión de Dios con la fe». ¿Es eso posible? En la Biblia no hay solución definitiva: Moisés vio a Dios cara a cara, pero «nadie puede ver a Dios y vivir» (Éxodo y Números). El N.T., lejos de facilitar la visión de Dios, parece excluirla taxativamente: Quem nemo vidit, sed nec videre potest $(1 \operatorname{Tim} 6,16)$. La visión de Dios es tema de la esperanza en la vida futura. Por lo demás, los místicos citan la Biblia a la buena de Dios, y no entran en discusiones histórico-críticas, es decir, en sentido auténtico. Lo que busca, por ejemplo, san Juan de la Cruz, es explicar su propia experiencia.

La fe del místico será pues "experimental», inductiva. Sus toques, lejos de ser "sobrenaturales», pueden llegar a "descomponer el cerebro". Además, esos toques no revelan una determinada causalidad, un espíritu bueno o malo: son signos, semeia, de una presencia y causalidad trascendente. Identificar esa trascendencia con un Dios cristiano, creador, libre y personal, es algo en lo que podemos "creer» o que quizá debiéramos «demostrar» rigurosamente. Esa fe del místico, que se impone, por lo menos como conditio sine qua non, tiene que abarcar tanto a los fenómenos como a la sindéresis, a la manera de una memoria sustancial que abarca el pasado, el presente y el futuro, dentro de una esperanza de la gloria venidera ${ }^{41}$. En este sentido, san Juan

el hierro. La deificación del hombre es pretensión platónica y estoica. San Agustín adujo una sola vez la palabra y luego la retiró de su vocabulario. Pero en el fondo se trata de una oculta pretensión, tendencia natural o necesidad humana; «ser como dioses». No podemos evitarlo de ningún modo, pues el hombre, tan relativo, está hecho con la necesidad de absolutizar. No hay remedio. El hombre sabe, más o menos, que jamás tendrá una sola partícula de divinidad, pero jamás renunciará a ese quid divinum que presupone en sí mismo. Se contenta con decir que Dios creó al hombre a su imagen, pero entiende que ahí está el secreto y el misterio, en esa uimagen dinámica» que Dios nos metió dentro. Esa imagen es la serpiente paradisíaca que nos repite «seréis como Dioses», sin ironía alguna. Esa serpiente paradisíaca está enroscada en el inconsciente, en el árbol de la Vida, Eva.

40. «La Palabra dio poder de hacerse hijos de Dios... sino que nació de Dios... pues de su plenitud hemos recibido todos...» (Jo 1, 12-16). Por la «participación en Cristo, participamos en Dios y llegamos a ser divinae consortes naturae (II P. 1,4) «renacidos, no de semen corruptible sino incorruptible por la palabra de Dios» (I P. 1,23), etc. Ya hemos visto en la doctrina de Sto. Tomás cómo hemos de entender esta doctrina en sentido teológico. Pero los cristianos buscaron también el sentido místico, justificando su postura con el concepto de la fe».

41. MARECHAL, J., Études sur la psychologie des mystiques, Paris, 2 vols. II, p. 35ss. Niega que san Juan de la Cruz admitiera la posibilidad de ver a Dios directamente en este mundo; pero luego comienza a dudar. En cambio, afirma la posibiblidad y el hecho el P. CRISÓGONO, Vida de san Juan de la Cruz. 2 ed., Madrid, 1950, I, 426. Niega también el hecho BLANCHARD, P., "Experience trinitaire et vision beatifique d'aprés saint Jean de la Croix» en Annee théologique, 
de la Cruz muestra ya su postura moderna, ya que su vida es «proyecto» o proyección, apoyándose, no en el pasado (Freud), como si sólo se tratase de biología, sino en el futuro (Adler), porque se trata de un fin, en el que el hombre se apoya para vivir. Tal es la relación profunda entre la memoria sustancial y la esperanza, pues son la misma cosa, con distinción virtual. Por eso necesita el santo un esquema convencional, aristotélico o no, para poder hablar de "virtualidades» o funciones»; pero necesita también liberarse del esquema cuando le conviene, porque habla de posturas personales: «soy yo el que recuerdo, pienso y amo, aunque con mis potencias» (san Agustín). Este subjetivismo moderno del místico castellano no se opone al objetivismo helénico: acentúa el papel del sujeto, pero no niega el objeto. Busca, como dijimos, «la objetividad interior» ${ }^{42}$.

\section{El orden de la voluntad}

¿Por dónde comenzar la catarsis de las potencias? Siguiendo la orientación, generalmente agustiniana, comenzaremos por la voluntad, y así nos atenemos a la dialógica o dialéctica trinitaria. En efecto, creemos que S. Juan comienza por la voluntad, por los apetitos, si nos atenemos al orden de la Subida. Cuando, al fin de la Subida, vuelve sobre la voluntad, el libro decae visiblemente y pierde interés. Parece que el santo iba a presentar un esquema estoico: gozo, esperanza, dolor y temor. Pero vemos que se contenta con sólo el gozo al que identifica sin duda con el amor. Vemos entonces que lo que nos propone desde el principio de la Subida es un ordo amoris, en el sentido de una vía purgativa.

Mas ¿por qué comenzar por la caridad, y no por la fe, cuando la fe es la puerta de toda actividad cristiana? Nos vemos obligados a suponer una «fe informada por la caridad"), si es que el santo no confunde ambas virtudes, diferenciándolas solo virtualmente ${ }^{43}$. De nada nos serviría recaer en un neoplatonismo, poniendo la esencia de la mística en el amor y no en el conocimiento, .... pues al hablar así, nos mantendríamos aún dentro del aristotelismo: en lugar

(1948) p. 289-322; si algunos textos sanjuanistas parecen decir lo contrario, tendriamos una contradición.

42. El concepto de la "gloria» es, pues, esencial para esta mística. No se trata aquí de trasformar ascéticamente la memoria, de manera que cambie de naturaleza, sino que la memoria es memoria desde el principio y continúa siempre siendo memoria y sólo memoria. No tiene pues por qué admirarse BORD, l.c., p. 251: «volvemos a encontrar la vacilación ya señalada entre memoria y sustancia. A veces el término memoria es suprimido y sustituido por sustancia». Asi, pues, la conversión y la trasformación progresiva de la memoria en el proceso místico, es sólo una progresiva manifestación de la gloria, en su sentido plenario o totalitario, como lo hace ver el mismo BORD, (Ibid. pp. 270ss.) sin necesidad de cambiar de órdenes, o pasarse del conocimiento al amor, o a otra potencia o virtualidad aristotélica, pues se trata de posturas personales.

43. BALTHASAR, l.c. p. 58. SCIACCA, M. F., La Interioridad objetiva. Murcia, 1955. 
de sustituir el racionalismo helenista por la caridad cristiana, lo que hariamos sería someter a Cristo a la dictadura aristotélica: deificaríamos al hombre con un amor "ciego» e irracional, del que nadie es consciente. La fe, esperanza y caridad de que hablan los cristianos no son «potencias» sino posturas, personas, sustancias. Son relativas, en cuanto se relacionan unas con otras por su objeto formal, pero son absolutas, sustanciales, en cuanto son personales ${ }^{44}$.

Así se comprende bien el esquema general de la Subida en cuanto vía purgativa, que comprende las noches activa y pasiva, del sentido y del espíritu ${ }^{45}$. El sentido es agustiniano, aunque se cite a Boecio: san Juan es subjetivista y apunta a una delectatio victrix ${ }^{46}$, que se da por supuesta y a una «autenticidad» de la virtud, en relación con la intención dirigida a Dios, que se da también por supuesta ${ }^{47}$.

Por lo mismo, la definición del "gozo" activo, y aun del pasivo, es subjetivismo moderno: sólo se atiende al "contentamiento de la voluntad» y no al «objeto formal». El santo engloba todos los objetos y bienes de cualquier orden, para combatir, no los bienes, sino los apetitos o apegos. Cuando al final del libro, vuelve sobre la voluntad, tan sólo le preocupa ya ciertas «supersticiones»" ${ }^{48}$.

\section{La catarsis de la voluntad}

Lo que antes hemos dicho de las "potencias sustanciales» en general, se comprueba al tratar de cada una en particular. Así, vemos que la voluntad penetra en el inconsciente, y es en su mayor parte inconsciente. ¿Qué significan esos que llamamos «impulsos», por ejemplo? No son conscientes, pero son

44. BALTHASAR, I.c., vuelve a pensar en una distinción virtual. La fórmula agustiniana decía que "hay que anteponer la necesidad de la caridad al gozo de la contemplación», porque en efecto, tanto el Cristianismo como el Helenismo podian radicalizarse y hacerse exclusivistas. $\mathrm{Pe}$ ro, en la realidad, en el hombre, se dan juntos el conocimiento y el amor. Hay una dialéctica abstracta (Cfr. PRZYWARA, E., AGUSTINUS, Leipzig, 1934, p. 34ss) que puede organizarse de diferentes modos, pero siempre serán abstracciones. $Y$ en sentido agustiniano, esa dialéctica es trinitaria; por ende, aparece siempre la voluntad-amor (Espíritu Santo) como consecuencia del entendimiento-ciencia (Hijo), en relación con el Padre-Memoria (Arché). Subsiste asi el principio "nadie ama lo que ignora». Por eso, la fe tiene que ser razonable y nadie puede aceptar una fe irracional «Nadie creería, si no sintiera la obligación de creer, y nadie creerá lo que ignora» is. Agustín). Pero quien cree, sabe, ama, odia, recuerda o busca, es uno persona, una sustancia. ORCIBAL disculpa al Santo, diciendo que es un «poeta», que su lenguaje es impropio, que no es aristotélico ni tomista, que quizá identifica las potencias con la sustancia, etc. (Cfr. ORCIBAL, I.c., p. 180: MOREL, I.c., II, 288.

45. Subida, I, 3s; III, 16ss.

46. Id. III, 16,2 Y Primera parte de la Subida.

47. Id., III, 16, y 17.

48. No merecen otro nombre esos "vicios» que el santo fustig. acer:a de las imágenes. oratorios, santuarios y ceremonias. Quizá en esto imita a otros autort: de su tieniro. Sabenos por ejemplo, que Fr. Luis de León escribió un tratadito sobre las supersticiones de Castilla. 
de la voluntad, ya que la sustancia no es inmediatamente operativa. Por lo mismo, el problema del "quietismo» sólo puede interesar a los aristotélicos. En san Juan de la Cruz no hay problema, pues todo es actividad enérgica: cuando el alma salió a la «noche», iba ya en amores inflamada y llevaba en el corazón una luz, más cierta que la luz del mediodía ${ }^{49}$. Las dificultades se producirán, pues, no en la voluntad, o en el entendimiento, sino en la «consciencia», en cuanto que los fenómenos místicos requieren un «arrobamiento», es decir, una situación «inconsciente» ${ }^{50}$.

El problema ascético parece excesivo en san Juan: parece ir más allá de los estoicos, llegando hasta los cínicos en su escarda de apetitos. En cambio, parece que descuida los aspectos positivos de la catarsis: lectura, meditación, estudio, discusión, ejercicios, ensayos, ascetismos múltiples, funciones cartáticas de la luz, etc. Santa Teresa se preguntaba si Dios tiene que esperar a que el hombre termine de desarraigar sus apetitos, y apuntaba al parecer, a ese rigor del místico castellano. El había experimentado los fenómenos místicos, cuando aún era muy imperfecta, lo que desorientaba a los teólogos ${ }^{51}$. Pero todo eso es aparente: si el alma está ya "en amores inflamada» y lleva en el corazón su lucecita, en cualquier momento puede sobrevenir el fenómeno, el

49. ALBRECHT, I.c. Dejando a un lado el absurdo problema del quietismo tropezamos con la «meditación sin contenido» de los orientales. Distingamos el problema teórico y el problema experimer $\%$. Llega un momento en que la meditación de contenido se hace imposible: el sujeto no pued $\epsilon$ sencer su estado «inerme», que parece una abulia. Es natural que entonces se hable de quietud, sueño, recogimiento, pureza de fe, noticias indistintas, generales, confusas, etc. Pero ese estado, lejos de ser quietista, revela una actividad más profunda, un inconsciente activo y más rico que comienza a subir, a emerger o aflorar de las profundidades del alma, como un continente sumergido. Los encefalogramas actuales prueban que aún en el sueño trabaja nuestro cerebro y más trabajará el espíritu. En cuanto al problema teórico, distinguiremos niveles, para no envolvernos en sofismas aristotélicos.

50. El problema del arrobamiento merece estudio aparte, pero en todo caso parece condición necesaria para una "visión». De otro modo, no salvaríamos su carácter «pasivo». Las «visiones» de cualquier linaje que sean, han de ser semejantes a los sueños o ensueños, a las visiones soñadas. Son pues fenómenos de inconsciente. Los manicomios y clínicas ofrecen abundantes ejemplos de pérdida del control consciente, de visiones, de lógicas diferentes, sin que podamos tirar una raya rígida entre lo "normal» y lo «anormal». El místico no es un enfermo, pero hay místicos enfermos y enfermos que no son místicos. Son cosas diferentes, y pueden darse juntas en un sujeto: la psicología se beneficia no poco de la mística y viceversa. Del mismo modo, es imposible tirar una raya rigida entre "consciencia» e uinconsciencia», pues hay zonas de penumbra, e incluso de "sobreconsciencia». Aun en el caso de Plotino aparece la contradicción en su "unión transformante»; no sería transformante, si se tratase sólo de "amor sin consciencia» (Cfr. TROUILLARD, J., La purification plotinienne, Paris, 1955, p. 97).

51. Santa Teresa parece protestar de que se exija demasiada perfección en la preparación ascética, estimando que los fenómenos místicos «los da Dios cuando quiere». Eso no significa que no haya conexión causal o física entre la ascética y la mística, sino que esa conexión no es tan "causal» como parece, pues implica en el sujeto ciertas disposiciones o cualidades previas. Así se entiende que los fenómenos se presentan «cuando Dios quiere». De todos modos, san Juan es más riguroso en esto que santa Teresa, y eso se debe a la experiencia, diferente en ambos. 
encuentro con la trascendencia. San Juan habla a principiantes, pero "místicos de hecho». El mismo amor es fuego purgativo, es purgatorio e infierno ${ }^{52}$, y también cielo para la «aventura perfecta».

¿Por qué, entonces, no nos ofrece san Juan un tratadito inicial sobre el amor, como lo hace por ejemplo Malón de Chaide, en la Conversión de la Magdalena? Porque san Juan no trata de otra cosa: su obra es un tratado sobre el amor. Sólo que ese «amor» no es conceptual, sino experimental, existencial: es enamoramiento, estado psicológico, lógico y metafísico. Ese amor es, no voluntad, sino persona, pues que lo invade todo: el místico ama, no sólo con su voluntad sino «con todo su corazón, con toda su alma, con todas sus potencias y sentidos..." Juan es una "voluntad inflamada», una sustancia o potencia sustancial, un «espíritu de llama». El «dolorido sentir» de Garcilaso es ya trascendente, como «subido sentir» o "altísimo sentir».

\section{Desnudez del entendimiento}

¿Qué significa esta fórmula? San Agustín renunciaba a la «mística de visión", para quedarse sólo con la visión, es decir, con el contenido o mensaje de la misma. Lo demás no le interesaba. ¿No nos colocamos con san Juan de la Cruz en el extremo opuesto? ¿No renunciamos al mensaje o contenido para contentarnos con la mera experiencia subjetiva? No. $Y$ la razón es que al hablar de «vaciar», nos referimos al contenido "empírico» tan sólo. Vaciar o desnudar el entendimiento es volverlo a dejar tanquam tabula rasa (Aristóteles). Pero no es vaciarlo de su contenido natural, de sus valores. En la plena desnudez del empirismo nos quedan el pensamiento y la atención, la memoria sui y la memoria $D e i^{53}$. Kant pensó erróneamente que sus categorías sólo eran leyes formales, sin contenido alguno, cuando en realidad son leyes $y$ contenido juntamente y «como los instintos», sólo necesitan objetos concretos para dispararse ${ }^{54}$.

52. BALTHASAR, I.c., II, p. 12ss.

53. Persiste pues la concordia entre Palestina y Grecia, entre la fe y la razón. Y resulta entonces que, aunque san Juan de la Cruz es convencionalmente aristotélico, es tơavia más pro. fundamente platónico, como le acontece también a santo Tomás de Aquino. En cuarito cristians. aprovecha la teoría de la fe, para superar el chorismós platónico y demás dificultades noeticas. Asi, recuerda que según Aristóteles, "cuanto más brilla el sol, menos ven el murciélago y la iechu. za" (Subida, II, 8,5,5,6,9, etc.). La fe cae bajo el entendimiento: "debajo de esta tinieb) s se jur.. con Dios el entendimiento, y debajo de ella está Dios escondido" (!d. II, 9,1). El Deus atrcoriditı : tiene asi una explicación dada por los místicos. El «debajo» es al inconsciente, y er l trabe: enérgicamente el entendimiento.

54. Muchas dificultades de los pensadores antiguos provienen de sue teorías de la ssns: ción. Suponían que los ojos emiten luz que ilumina los objetos; como esa lu? es escasa. es tân: bién necesaria la «luz externa», especialmente la del sol. Eso sì apličaba al entendimiento e incl:so a la fe. 
En esa perspectiva hablaba san Agustín del grandius aenigma (vemos y no vemos a Dios), y en ella parece hablar san Juan. En efecto, para hablarnos de la «unión con Dios», comienza afirmando que Dios está ya en nosotros desde el principio por esencia, presencia y potencia: parece pues que no se refiere al entendimiento, sino a la consciencia ${ }^{55}$. "Limpiar la vidriera" es remover un obstáculo que nos impedía ver. El entendimiento humano, por sí mismo, sería pues capaz de ver a Dios en este mundo, si interpretamos bien el término «Dios" como supervalor. Si no lo vemos normalmente, es por falta de diafanidad y trasparencia, es porque hay algún óbice, y por eso es necesaria la catarsis ${ }^{56}$

Es inútil recurrir a la fe, como oponiéndola al entendimiento. Sin entendimiento no hay fe, ni en acto ni en hábito, ni en contenido. Pero el místico se debate, no sólo con las dificultades propias de los filósofos y teólogos, sino también con las suyas propias, con las que brotan de su experiencia personal de la razón, de la revelación y de la experiencia del inconsciente. Palpa la trascendencia, y sólo con la fe puede identificarla con su Dios. Ve diferentes niveles o planos: una cosa son sus «visiones», y otra muy diferente son sus "deducciones». Trata de identificar la "fe verdadera» con la "fe viva», pero no puede negar el lenguaje convencional y tradicional. Llega a la conclusión de que la visión beatífica es sólo la continuación o perfección de su fe viva, la remoción del "último velo»; pero sabe muy bien que en este mundo vive "en régimen de fe» $y$ en "régimen de pecado original», es decir, en "régimen penal» ${ }^{57}$. Y por eso se convierte a sí mismo en tierra de sudor y de angustia.

¿Habrá pues en este mundo visión de Dios, intuitiva e inmediata? Parece que, a pesar de las dificultades ya apuntadas, san Juan se inclina a aceptarla positivamente, aunque como excepción y de pasada, pues no alega ningún "medium per quod (imagen, especie, etc.). Algunos lo niegan, o ponen cortapisas, pero quizá lo hacen por miedo al panteísmo ${ }^{58}$. Quedamos pues dudando, si el problema se plantea formalmente.

55. Ya dijimos que Plotino incurría en esa contradicción. El amor no «trasforma», a no ser por el consurso con el entendimiento o consciencia.

56. El paso de la fe teológica a la fe mística es insensible. A veces se dan juntos, como se ve en los Santos Padres y grandes Escolásticos. La Catarsis completa será pues negativa y positiva.

57. Volvemos al sentimiento original de la religión como Supervalor. $Y$ la fe radical respondería a ese sentimiento o instinto religioso. La labor del místico consistirá en ir adaptando esa fe a la revelación positiva. De ese modo, cuando todo va bien, la fe se enriquece con la revelación y la revelación se enriquece con la experiencia mística. El místico es ya el cristiano perfecto, unificado en Jesucristo. Ante él van cayendo los obstáculos de la "visión», los "velos cubren la verdad»).

58. Pero no nos fiemos de apariencias. Porque también afirma el santo que vivimos en régimen de fe, y no de visión, y que el último velo subsiste siempre. 


\section{El saber sustancial}

Ya que se opone al «saber potencial», coincidirá en principio con el prereflexivo, prelógico, preconsciente, según la denominación de diferentes autores. Pero al mismo tiempo será "supraconsciente», es decir, superación del conocimiento consciente. Desde un punto de vista teológico, por razón de su causa y de su carácter, lo llamamos «sobrenatural» ${ }^{59}$. La explicación de esta actual condición humana sería el pecado, es decir, la evidencia de que vivimos en régimen anormal, penal ${ }^{60}$.

¿Podríamos entonces suponer que el paso de una memoria Dei a un intellectus Dei, contando con el auxilio ordinario de la gracia divina, es una tarea "técnica", encomendada a la ascética o a un método semejante? Parece que la Subida sugiere que la ascética prepara el camino a la mística, pero no determina su aparición en el campo de la causalidad, ya que el fenómeno místico se produce "cuando Dios quiere», es decir, como un puro e inesperado don de Dios. Claro está que se mantiene la duda. El fenómeno místico se produce "cuando Dios quiere», pero ¿cuándo quiere Dios? Quizá cuando se reúnen los requisitos que la ascética trata de allegar. En todo caso, el aducir una intervención directa e inmediata de Dios es un problema que sólo la revelación puede resolver; atañe pues a la competencia de la teología y no es evidencia mística, por lo menos de ordinario. Quizá el psicólogo llarma inconsciente a lo que el teólogo llama gracia divina, y así es inútil discutir en el campo racional. Sólo que es necesario escuchar al místico, puesto que tiene una más profunda información ${ }^{61}$.

Si entendiéramos el saber místico como desarrollo final o apoteosis del conocimiento natural y radical del hombre, comprenderíamos mejor el valor de la ascética, y el carácter «normativo» de la mística de san Juan de la Cruz. Al vaciar las potencias, provoca un «horror al vacío" y así remueve obstáculos, produce nuevas energías, desarrolla cualidades, reintegra y unifica la vida interior en una sola «idea obsesiva». Esa «idea» no es platónica ni aristotélica, ni siquiera pertenece al entendimiento. Desde un punto de vista subjetivo, es una situación semejante a la de los enamorados obsesivos, incapaces de valerse, según la fórmula de santa Teresa; desde un punto de vista objetivo, es la objetividad interior, que el místico llama Dios. Hay pues una cierta concordia de la iluminación noética con la iluminación, o formación o unión ontológica ${ }^{62}$.

\footnotetext{
- 59. "El'hómbre es «imagen» de Dios. Tendremos pues que hacer al hombre a imagen de Dios, siguiendo la luz de la revelación, y no hacer a Dios a imagen del hombre, racionalizando a Dios. Un aristotélico cae fácilmente en la tentación, como le aconteció a Schmaus.

60. Otra vez platonismo y cristianismo tratan de ponerse de acuerdo.

61. La ascética no obra mecánica o físicamente: puede un gran asceta no llegar nunca a entrar en la mística, pues necesita otras condiciones previas.

62. El insconsciente conoce inconscientemente. Pero al desarrollar su energía, puede aflo-
} 
No excluímos una causalidad directa e inmediata, si puede comprobarse ${ }^{63}$; pero ese problema hay que discutirlo con los teólogos ${ }^{64}$. Lo que es ya claro es que tenemos algo más que «conocimiento gnoseológico» y que el humus de la mística es la soledad del corazón: "La teología mística es sabiduría secreta, la cual dice santo Tomás, que se comunica e infunde en el alma por amor... a oscuras de las potencias... Pero no hay decir lo que el alma tiene, ni la sacarán más que términos generales» ${ }^{65}$. "Parece que la colocan en una profundísima y anchísima soledad, como un inmenso desierto, que por ninguna parte tiene fin... Echa de ver cuán bajos y cortos e impropios son todos los términos y vocablos» ${ }^{66}$.

\section{Las aprehensiones}

Puesto que, en el fondo, aparece un sistema aristotélico del conocimiento, tenemos que aceptar dos conclusiones elementales: 1) el conocimiento místico de san Juan depende de la noética aristotélica, y se mantiene o cae con ella; por ese su lado débil, es necesario acudir a mejores teorías acerca del conocimiento místico ${ }^{67}$; 2) pero como san Juan se atiene a su propia expe-

rar a la consciencia y hacerse consciente. Es claro que cuando el místico trabaja habitualmente con el inconsciente, llega a una perfección, que el psicoanálisis adivina, pero comprueba muy mal en sus clientes, ya que suele preferir enfermos, niños, tipos elementales.

63. Los fenómenos místicos aparecen cuando Dios quiere. Pero nos preguntamos cuándo quiere Dios. Crea un alma cuando quiere, pero quiere cuando hay una generación.

64. Así subsiste en san Juan una serie de indeterminaciones. Dios obra en la naturaleza y en el fenómeno místico, pero de diferente manera. Dios hace aparecer fenómenos, pero puede valerse de mediaciones.

65. Noche Oscura, 11, 17,3ss.

66. Id. n. 5. Es pues «humanamente no sabiendo y divinamente ignorando (Id. 6), o como dice el verso: "y quedéme no sabiendo, toda ciencia trascendiendo», del poema "entréme donde no supe». Es pues un conocimiento tan radical que recuerda el socrático "sólo sé que no sé nada». $Y$ por eso, aunque por un lado parece el colmo de la ciencia, por otro, parece el principio de la misma, su principio y fundamento.

67. El que un conocimiento sea «místico» no impide que sea "conocimiento». Por ende, ha de mantener la «relación gnoseológica». Cfr. HARTMANN, N., Grundzüge einer metaphysik der Erkenntnis, 4 ed., Berlin, 1949, p. 44ss. ALBRECHT, C., Das mystische Erkenntnis, Bremen, 1958. Se ve claro hasta qué punto puede la mística hablar de un "conocimiento» propiamente dicho, ya que nos encontramos con una relación, que es algo más que psicológica y lógica, y algo més que metafísica. En su aspecto metafísico, que es el que aquí nos interesa, entraríamos ya en un campo muy especial y profundo. De hecho, san Juan de la Cruz en la Noche Oscura, insiste en que "conocemos" por la fe y por el amor, y eso no es propiamente conocer, sino creer y amar. La mistica "cristiana» incorpora el conocimiento místico de la experiencia al conocimiento teológico de la fe y de la revelación. Tenemos. pues, dos fuentes distintas. Además hay que contar «no sólo con i in fluido de amor, y un aura de belleza, no sólo con el fenómeno de la influencia personal, no sćlo on la contemplación de la luz, no sólo con las fórmulas y sus resonancias de amor y de entrege, sino también con las dificultades, en cuanto es invitación e imposición. Por ende, desde

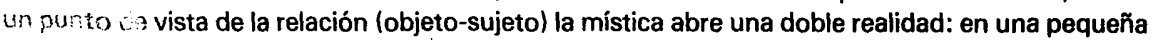


riencia, sus puntos de vista tienen valor, que llamaríamos absoluto en lo que toca a la experiencia. En la Subida nos expone brevemente su modo de ver. Utiliza en general el término "aprehensión» para comprender todo linaje de conocimiento, $y$ en ese sentido cree que se puede utilizar también genéricamente el término "visión», siguiendo en esto a san Agustín ${ }^{68}$. También sigue a san Agustín, al aplicar genéricamente el término «sentir», como Descartes utilizó el término "pensar» o Schleiermacher el término "sentir» ${ }^{69}$. Todo eso no le impide admitir un sentido propio y específico para términos tales como visiones, revelaciones, locuciones, sentimientos, cuando se trata de objetos concretos ${ }^{70}$.

Hay alguna dificultad en el término «sentimiento», dada su ambigüedad. Ya que lo específico no cuenta, cuando se trata de la unión con Dios, puesto que de todo ello ha de vaciarse el alma, hay «sentimientos» de gusto, olor $y$ tocamiento, que deberán también ser eliminados. La dificultad proviene de que hay un toque, o junta, o sentimiento que es uinteligencia mistica, confusa, y oscura», que se llama también "noticia oscura y amorosa», que se identifica con la fe, y que no puede ni debe ser eliminada; en efecto «mediante esta noticia amorosa y oscura, se junta Dios con el alma... porque es la fe; y sirve en esta vida para la divina unión, como la lumbre de la gloria sirve en la otra de medio para la clara visión de Dios» ${ }^{71}$.

Parece pues que deberemos distinguir aquí el campo de la fe teológica y el campo de la experiencia mística. En cuanto experiencia, la noticia, toque, o junta, o sentimiento, es evidencia de una trascendencia en el sentido pasivo que antes hemos dicho. Pero la fe atestigua que se trata de un Dios personal $y$ cristiano. Es lo que explica el mismo santo: «fundarse en lo que no ve, ni siente, ni puede ver ni sentir en esta vida, que es Dios, el cual es incomprensible y sobre todo; y por eso nos conviene ir a él por negación de todo ${ }^{72}$. Es claro que tales toques o noticias tienen carácter experimental: "ellas mismas son la misma unión; porque consiste el tenerlas en cierto toque que se hace del alma

pàrte es un auténtico acto de conocimiento, en el que el objeto es considerado como presente; pero en su mayor parte es "captar en fe», y por lo mismo es una realidad que es gustada como obra de la fe) (ALBRECHT, l.c., p. 326).

68. S. AGUSTíN. Ep. 147, 4s PL. 33,598. De Gen. ad litt. XII, 7,6 PL 34,459. Al mismo tiempo, Agustín se acerca a una identificación de la sensación con la «consciencia de esa sensación», ya que una sensación inconsciente o desapercibida no le interesa. Est enim et sensus animae: atribuye asi al espíritu la sensación, el sentido. $Y$ a esto se acerca san Juan de la Cruz.

69. El Cogito cartesiano es también la consciencia y ese es su defecto, ya que no conoce un «pensamiento inconsciente» es decir metafísico, subconsciente, prelógico, prereflexivo, etc., como sus comentaristas posteriores. En cambio en Schleiermacher comienza ya a manifestarse una visión del susconsciente.

70. Subida, II, 23,2.

71. Id., II, 24,2 .

72. Subida, II, 24,5 . 
en la divinidad y así el mismo Dios es el que allí es sentido y gustado". "Con uno de ellos se daría por bien pagada de todos los trabajos» ${ }^{73}$.

El santo distingue dos clases de sentimientos: los de la voluntad y los de la sustancia del alma. Añade que hay muchas clases de ambos, y que hay uun subidísimo sentir de Dios, y sabrosísimo en el entendimiento, al cual no se puede poner nombre, tampoco, como al sentimiento de donde redunda». Dado este carácter experimental, resulta inútil reducir la mística a la «contemplación infusa», olvidando el complejo de la «noche oscura». ${ }^{74}$.

\section{La memoria como soporte fundamental}

A. Bord cree que la teoría sanjuanista de la memoria es «agustiniana»; expone tres sentidos diferentes de esa memoria (reminiscencia, retención y receptáculol, pero no logra una exposición satisfactoria, porque no ve la memoria como soporte de la duración y de la extensión. Mejor ve el problema E. Gouhier en el epílogo de ese libro; pues, recordando a Bergson, ve la memoria como "duración» en la que cada instante permanece, en la que el pasado no pasa ${ }^{75}$. Con mayor sencillez y fuerza lo había expresado San Agustín: sin la memoria no sería posible ni siquiera la sensación, ya que el animal no podría unir o relacionar dos instantes distintos. Si al decir $M a$, hubiéramos olvidado la sílaba $R o$, nadie diría ROMA, o de nada serviría decirlo. Sin la memoria no podríamos relacionar el ayer, con el hoy, o con el mañana, ni mentar al ser, porque necesitamos un soporte que sea sustancia del alma, personal consciente $\mathrm{o}$ inconsciente, situación estado-dinámica» ${ }^{76}$, etc.

Bord señala bien las vacilaciones de san Juan de la Cruz, al no adoptar una postura firme, queriendo juntar lo antiguo y lo moderno $\pi$. Pero al fin en san Juan, dice Bord, la memoria viene a coincidir con el alma, pues al mencionar las tríadas, dice "entendimiento-voluntad-memoria», o también «entendimiento-voluntad-imaginativa», «entendimiento-voluntad-alma», «entendimiento-voluntad-sustancia ${ }^{78}$. Ese deslizamiento del sentido desde la memoria hasta el alma deja sospechar el privilegio de la memoria por relación al entendimiento y a la voluntad ${ }^{79}$. Bord tiene razón y hace bien en mencionar a Bergson y al inconsciente. Concluye taxativamente: «San Juan de la

73. Id., II, 26,2.

74." Id., II, 32,1.

75. BORD, l.c., p. 7.

76. La teoría agustiniana de la sensación muestra que sin la memoria no es posible la sensación misma, ya que es necesario unir dos instantes de tiempo o dos puntos de espacio. Por eso hay que contar con la duración y la extensión, para dominar las leyes del tiempo y del espacio.

77. BORD, I.c., p. 90ss.

78. Id., p. 62 .

79. Id., p. 93. 
Cruz se inspira en Agustín» ${ }^{80}$. Pero desearíamos puntualizar un poco mejor el problema, pues de ese modo, la memoria agustiniana es el principio y fundamento de toda mística. Así podriamos aceptar con el mayor gusto la sentencia de Bord: «la memoria es una potencia del espíritu; por ende, de derecho, está hecha para la unión con Dios; sólo que, de hecho, su finitud y su desarreglo en el mismo punto de partida la hacen incapaz de esa unión ${ }^{81}$.

\section{La memoria, como herencia o naturaleza}

Dios es cualitativamente trascendente, pues no entra en los predicables de Aristóteles. De nada nos sirve entonces el cúmulo de ideas y palabras que el empirismo nos puede ofrecer. Por otra parte, teológicamente hablando, Dios habita en una luz inaccesible y el hombre ni le ve ni puede verlo. Estamos pues ante la paradoja que trataba de aclarar san Agustín. El hombre es un deseo de ver a Dios y ese deseo supone que sabe ya por su misma naturaleza o herencia quién es Dios o qué es Dios. Pero sabe también que Dios es incomprensible e inefable y que su único modo de abrirse camino en este problema es volver a partir de su conocimiento «natural, radical, fundamental», que es su misma condición humana, o bien hablando objetivamente ula presencia dinámica de Dios en el espíritu humano. Entonces se explica por qué se refugia o retira en una «teología negativa», hasta llegar a un minimum, a una roca fuerte, que es un pensar o un sentir «metafísico»; sobre la base de una experiencia gnoseológica. Pero luego trata de sacar de ahí un sentido positivo: se ha quedado con un remanente elemental, cuando habla de ciencia, misericordia, justicia, bondad, etc., pero ahora exalta ese residuo hasta hacer una teología del exceso y de superación: ¡Allá Ajbar! San Agustín, por ejemplo, partía de una teología negativa, pero luego, después de agotar todos los superlativos, al hablar de Dios, recurría a una ley, que ha dado pie al argumento ontológico de san Anselmo: todos los hombres, de cualquier condición, han tratado siempre de atribuir a Dios todo lo mejor que han pensado o adivinado, y eso lo hacen, diríamos, por exigencia de su sentido común o por su misma razón humana radical. El místico añade todavía el misterio de su experiencia personal del inconsciente ${ }^{82}$.

80. Id., 96 .

81. Id., p. 99. Vemos pues el proceso del «récalentamiento del madero húmedo. Noche Oscura, II, 9.4; II, 10,1. Ese proceso es un ahondar hacia la memoria metafísica, y asi dice bien BALLESTERO «hacia el olvido y el desierto». Ya no está tan bien dicho que la purificación de la memoria es el primer estadio de catartización, cuando es el último y más elementar: recaer en el aristotelismo, es condenarnos a no entender nada.

82. BALLESTERO, M., Juan de la Cruz. De la ausencia al olvido, Barcelona, 1977, p. 197. El libro procede con agudeza al presentar los análisis estructurales, pero está desenfocado filosóficamente; así sus conclusiones se vuelven caprichosas y gratuitas. 
Así la razón y la fe se juntan para obligar al místico a explicar su experiencia personal, mediante un recurso al conocimiento metafísico o ultranoético, y a la gracia divina. De ese modo el místico se empecina en escudriñarse a sí mismo, buscando en su memoria la raíz última del hombre ${ }^{83}$. Insistirá, pues en que Dios hizo ya al hombre a su imagen, y en que esa imagen de Dios, estado-dinámica, está siempre presente y activa en el hombre; pero eso mismo hará con la gracia divina, tomándola como arché o principio de divinización, según la doctrina teológica cristiana. Insistirá, pues, en que no le interesa el campo empírico, del que procura limpiarse y vaciarse, pues sólo le interesa el subsuelo del hombre, esa ley que Kant creía "formal», y que es material y formal.

No hay dificultad alguna en reconocer la trascendencia, pues, hoy la aceptan con facilidad la filosofía, la sociología y la psicología mismas. Naturalmente, la trascendencia del místico, es «evidente», es decir, es más clara, profunda y convincente que la filosófica y la científica. Pero para identificar esa experiencia con Dios, necesita la fe, la revelación. Hay pues, diferencia esencial entre un místico cristiano y un místico budista en cuanto a la explicación, aunque haya coincidencia en la experiencia personal. $Y$ esto no es fideísmo, como si sólo se tratase de una imposición externa del dogma. Yo me contento con presentar la fe, por lo menos como conditio sine qua non. Veo que san Pablo arguyó así frente a judios y gentiles, y que desde Amós no se ha resuelto el problema de la discreción de espíritus ${ }^{84}$.

\section{La memoria es la esperanza}

Esta memoria, que es el ser del hombre, que abarca el pasado, el presente y el futuro en una duración y en una extensión, acentuando el futuro, es la que, como potencia, relaciona san Juan con la esperanza. El místico, interiormente unificado, comienza a dejarse guiar $y$ conducir por un «conocimiento

83. Es curiosa la conducta del místico, cuando por un lado afirma que su explicación de la visión de Dios ha de ser ininteligible, porque es inefable, y por otro lado se empeña en explicarnos algo que es inexplicable. Eso prueba que el místico no puede renunciar a su experiencia extraordinaria, aunque no acierte a explicarse a sí mismo. Nos explica también por qué santa Teresa distingue entre la experiencia mística y el saberla explicar como dos «mercedes» diferentes de Dios. Porque tanto la gracia experimental como la explicativa tienen que brotar «de la potencia del alman, ya por singular favor de Dios, ya por un fenómeno del inconsciente.

84. Santa Teresa y otros místicos confirman que, después de algún éxtasis, el mundo visible les parecía enteramente nuevo y nunca visto, animado por otra luz y otras energías. Cfr. nota 71. Era sin duda ella la que cambiaba. Y aunque san Juan de la Cruz tiene mayor capacidad crítica, es claro que no podía ni siquiera plantearse el problema de la duda sobre la identificación de la trascendencia con el Dios cristiano. Precisamente esa, si se quiere, convicción ciega ayuda no poco al fenómeno mistico, pues permite una mayor unificación interior y no admite disociación alguna. 
instintivo" o subconsciente, dejándose llevar por la misma naturaleza. EI místíco siente la impresión de una "contemplación infusa», producida por Dios, y asi la luz es tiniebla y la tiniebla es luz. A este mundo extraordinario de las profundidades del alma nunca se asomó Aristóteles. El madero húmedo termina convirtiéndose en llama viva y la vidriera sucia se convierte en diafanidad. "Le parece que todas las cosas son extrañas y de otra manera que solían ser...» "Aquí le parece al alma que anda fuera de sí, en penas. Otras veces piensa si es encantamiento el que tiene, o embelesamiento, $y$ anda maravillada de las cosas que ve y oye, pareciéndole muy peregrinas y extrañas... y con estos dolores viene a parir el espíritu de salud ${ }^{85}$. No hay que pensar, pues, en el "olvido» de que habla Ballestero en el lugar citado.

Bord distingue bien entre espera y expectación. «Esperar» es lo propio de una memoria orientada hacia el futuro, el paso de la potencia al acto. También san Agustín había domado el lenguaje latino, para hablar de spes y expectatio. Es el espíritu paulino, que repite: spectantes beatam spem et adventum gloriae. Tit 2,13», «expectantibus revelationem Domini (1 Cor 1,7). En esa relación memoria-esperanza es donde mejor se ve que san Juan ha roto con la escuela ${ }^{86}$.

Bord piensa que en san Agustín no hay indicaciones precisas sobre la relación memoria-esperanza, o sobre la esperanza sobrenatural. $Y$ así recurre a Lain Entralgo y a H. Sansón, para buscar esas indicaciones. Pero no se da cuenta de que el mismo concepto de memoria lo implica todo, y entonces, una de dos: o sobran esas indicaciones precisas, o tales indicaciones deben irse desenvolviendo a partir del sistema, y no como añadiduras aristotélicas, por ejemplo. La memoria es temporalidad o duración y es espacialidad o extensión, y abarca por igual a lo natural y a lo sobrenatural. Es pues el «ya, pero todavía no" de la Esposa, según san Pablo ${ }^{87}$. De ese modo, la relación memoria-esperanza es en san Juan de la cruz una clave para penetrar mejor en su pensamiento.

\section{El olvido final}

Podríamos quizá admitir el "olvido», de que nos habla Ballestero, en el sentido en que habla Enrique Gouhier, en el Prólogo del libro de Bord: «hay

85. Noche Oscura, II, 9,3.

86. BORD, I.c., p. 209. Dice bien BALLESTEROS: «memoria abierta a lo que aún no ha sido" (BALLESTERO), I.c., p. 209). Por eso es imposible el «colapso de sí a sí» (Id., p. id.). Quizá tiene también razón BALLESTERO, al constatar que san Juan se queda vacilante entre su tradicionalismo y su modernidad. P. CRISOGONO, san Juan de la Cruz. BAC, Madrid, I, p. 122).

87. BORD. I.c., p. 212; LAIN ENTRALGO, P., La Espera y la Esperanza; /d., "La memoria y la esperanza" en Real Academia de la Historia, Cfr. Revista de Espiritualidad, (1954) p. 385.SANSON, H., L'Esprit humain selon saint Jean de la Croix, Alger (PUF), 1953. 
una noche de la memoria, que la vacía de todo lo que ella contiene en el orden del «tener». $Y$ añade, justificando a Bord: «entonces aparece el nexo paradójico con la esperanza: es nexo paradójico, ya que establece correspondencia entre una facultad vuelta en apariencia hacia el pasado y una virtud que mira al futuro». Bord, por su parte, se explica así: "cuando la memoria no se repliega sobre sus adquisiciones, nada le impide acostarse con Dios; la memoria se termina en esperanza, como el entendimiento en fe, $y$ la voluntad en caridad. También utiliza Bord la fórmula feliz: «liberar la memoria»: es dejarla libre, desnudarla, (Alétheia), curada de las "heridas», como diría el san Agustín platonizante. Esa memoria desnuda sería ya «pura mirada, pura potencia natural y radical frente a un Dios que se acerca en la tiniebla luminosa, que viene a nuestro encuentro y a quien ya adivinamos: por eso nos altera los nervios y la sangre, porque «nos hiciste Señor para Vos» (San Agustín) ${ }^{8}$.

El «olvido» alcanza también el inconsciente en cierto modo, ya que si bien parece que ese inconsciente no está a nuestro alcance, de hecho lo está de algún modo y podemos influir en él e influimos sin duda constantemente. El encuentro con Dios no será pues un mero «encuentro noético» o relación noética, sino también encuentro lógico, psicológico y metafísico, encuentro personal y sustancial. Así el "olvido" que es noche y resultado de la noche y del espolio total, libertad absoluta, es una suerte de vuelta a la raíz, a la tabula rasa, pero en el sentido de inocencia original, o condición de Adán en el paraíso. El acierto de Bord es grande al relacionar los textos de san Juan con los de las Confesiones de san Agustín. Bord propone que se hable de una «patrogonía espiritual» ${ }^{89}$.

88. BORD, I.c., pp. 7,8, 101-116, 115 y 191. SAN AGUSTIN, Confessiones X, 20,29 PL $32,791 \mathrm{~s}$. Aquí «el orden del tener» corresponde a lo que hemos llamado "empirismo». Cuando decimos el refrán «la esperanza es lo último que se pierde», alegamos una gran verdad, ya que esa esperanza no mira sólo al futuro en extensión de tiempo, sino también a la profundidad, en la condición humana o sustancia del alma. El sentido de las teorías existencialistas sobre el «proyecto" es que el hombre mira al fin desde su principio y por lo mismo podemos decir que "el hombre es esperanza», o que "vive en esperanza». La esperanza es, pues, primariamente la sustancia del alma, aunque secundariamente también la fe y la caridad son la sustancia del alma.

89. BORD, I.c., p. 190s. SAN AGUSTíN, Confess. X, 30,41 PL 32,796. Habla aquí san Agustín de los sueños eróticos, de los que no somos responsables en el terreno "ético» y que sin embargo revelan nuestro «ser». Un sujeto, que en vigilia rechaza todas las sugestiones eróticas, quizá las admite en sueños, porque no es responsable, porque sus "potencias» no funcionan bajo el dictado de la razón ueducada» y domesticada. Pero, quizá, resiste también en el sueño, y eso demuestra que su castidad es mucho más perfecta, es casi «sustancial». Los Padres del yermo estiman de ese modo que un monje perfecto, no admite sugestiones pecaminosas ni aun en sueños. Pero la ética no alcanza a esas profundidades. $Y$ en ese sentido habla san Juan de la vuelta a la inocencia original, como se ve en Noche, II, 24,2 y 3 . Tal inocencia, lejos de implicar ignorancia del mal, implica uso de una perfecta sabiduría, como acontecía en Adán, según los teólogos (Cfr. Cántico, 26,14. Subida, II, 26,14 y II, 29,2). Es la patrogonia, de que habla BORD, p. 192, refiriéndose a las dos interpretaciones, la histórica y la metafísica, que hallamos expresadas en el Cántico, 37,5, según las dos ediciones, $A$ y $B$. Tenemos pues un "olvido» que consiste en "no poder olvidar» o "no poderse valer», que llamábamos antes "amor obsesivo" y que pudiera explicarse como «unión transformante». 
Este olvido final es el que ordena la mística, haciéndola auténtica y "buena». Podría parecer que la mística es demasiado individualista, ya que habla siempre de psicologías y mundos interiores. Sin embargo, ya hemos advertido que el término «interior» es ambiguo, ya que puede designar un «mundo interno" y un "mundo eterno», sobrehumano. La mística castellana aparecía en una época de efervescencia y de polémica. Teresa de Jesús era una «reformadora» y la mística estaba al servicio de esa "misión». La mística carmelitana tenía carácter social y carismático. No interesaba la exaltación del místico, sino el mensaje de reforma y la colaboración en esa reforma. Este criterio era el que habían comunicado a Teresa los santos Pedro de Alcántara y Francisco de Borja, y ese criterio es el que había predicado Teresa a Juan de san Matías, al sugerirle el nombre de Juan de la Cruz, como en los tiempos biblicos. Juan era, pues, un soldado, alistado en una empresa o aventura $y$ fuera de ella carece de sentido. Por desgracia, como repetiremos, Castilla olvidó la "misión» de sus místicos ${ }^{90}$. Sin embargo, los reproches no alcanzan a Juan de la Cruz, el cual se anonadó también a sí mismo, como Cristo.

\section{Cristocentrismo y trinitarismo}

Pocos autores hablan de un "cristocentrismo" en san Juan, porque el santo habla poco de ese tema. Pero hay aqui una dialógica inevitable, y por lo mismo un sistema cristiano, que es una ley y una necesidad, cuando se llega a las últimas consecuencias. No basta, pues, recurrir a las citas, explícitas o implícitas, pues quizá es más importante lo que deja adivinar, lo que se presupone. Cristo es no sólo un objeto de estudio, sino el camino, el método o instrumento, de una visión global de la existencia. Por eso Florisoone insiste tanto en el Cristo dibujado por san Juan, y puesto de relieve por Dalí, el Cristo crucificado entre el cielo y la tierra, como puente. Todavía hoy la "cristificación» de Teilhard de Chardin trata de expresar una ley y una necesidad. Si el Verbo hecho carne reúne el tiempo con la eternidad, lo natural con lo sobrenatural, lo sensible con lo ideal, Cristo es también la revelación del Padre, es decir, la revelación de la memoria. En esa revelación se juntan el principio el medio y el fin, el origen, la historia y la escatología. Por eso cuando el lector se

90. BALTHASAR, (/.c., p. 65s' objetaba que una «mística de divinizaciớn» tal como la predica aparentemente san Juan, contradice al espíritu de Cristo, el cual se anonadó (Kenósis), desvistiéndose de su forma de Dios y adoptando la forma de esclavo. Eso es verdad, pero la objeción no toca a san Juan y a su umistica de la noche". Aqui comprobamos la desorientación de la polémica Poulain-Saudreau, que discutía "gracias de oración» o "contemplaciones infusas», y no hablaba del mensaje, de la misión, del profetismo, del carisma público. Precisamente por eso San Agustín aceptaba la mística por su mensaje, por su «visión» o contenido, y dejaba a un lado todo lo demás (S. AGUSTIN), De Genes. ad Litt. XII, 18,39 PL 34,469. 
detiene a meditar algunas citas especialmente diáfanas, comprende al momento que el cristocentrismo es para san Juan una ley y una necesidad ${ }^{91}$.

Lo mismo ocurre con la dialógica trinitaria. No entra el santo en especulación sobre la generación del Hijo como inteligencia, o en la procesión del Espíritu como voluntad, o en la presentación del Padre como memoria. Pero el sistema lo reclama y así, cuando los textos llegan a desarrollar la doctrina, es inevitable la referencia: «Dándome inteligencia divina, según toda la habilidad y capacidad de mi entendimiento, y comunicándome el amor según la mayor fuerza de mi voluntad, y deleitándome en la sustancia del alma con el torrente de tu deleite en tu divino contacto y junta sustancial, según la mayor pureza de mi sustancia y capacidad y anchura de mi memoria" ${ }^{92}$. Este texto nos permite ver que la memoria corresponde al Padre y que es el principio, ya consciente o potencial, ya inconsciente o sustancial, del entendimiento y de la voluntad. Pero, como en ese mismo pasaje, san Juan interpreta el amor, ya como sustancia, ya como potencia, deducimos que en su pensamiento, los términos memoria, entendimiento y voluntad, pueden entenderse, ya como sustancia, ya como potencia, según a lo que se opongan, ya ad extra, ya ad invicem. En suma, se retiene el punto de vista de san Agustín, y por lo mismo aquí la filosofía depende de la teología. Es la doctrina trinitaria la que nos explica la dialógica de las potencias humanas; por lo mismo, es la Biblia y no Aristóteles, quien decide la solución del problema ${ }^{93}$.

Según lo dicho, tiene la mayor importancia la doctrina que se expone en la llama sobre las cavernas del sentido, es decir de las «potencias». El entendimiento se vacía de noticias empíricas, pero se le infunde la noticia general y oscura; la voluntad pierde las aficiones particulares, mientras que la memoria, no sabiendo ya san Juan qué decir, pasa al orden de la realidad existencial. Así en el entendimiento se produce la sed de Dios, en la voluntad el hambre de Dios, mientras en la memoria hay «deshacimiento y derretimiento» del alma por la posesión de Dios ${ }^{94}$.

91. "Yo buscaba un método para robustecerme y hacerme idóneo para gozar de Dios. Pero no lo tuve hasta que me abracé al Mediador entre Dios y los hombres, el hombre Cristo Jesús bendito por siglos, que me llamaba y decía: Yo soy el camino, la verdad, y la vida" (SAN AGUSTÍN Confessiones, VII, 18,24 PL 32,745). FLORISOONE, I.c., DOM GOZIER A., Jean de la Croix. Présence dans le silence, Declée, Paris, 1976, 12ss: «la venida de Cristo vuelve del revés el significado del Todo-Nada». Cfr. BALTHASAR, I.c. Cfr. JUANA DE LA CRUZ, Le Christ chez S. Jean de la Croix, Revue Carmel $(1967)^{2}{ }^{2}$. Cfr. STEIN, E., Le science de la croix, Nauwlaerts, 1975.

92. Llama, I, 9.

93. Aquí fue donde M. Schmaus cometió su equivocación fundamental, creyendo que san Agustín aplicaba a la Trinidad, la psicología humana, y no viceversa.

94. «Ni tampoco hay que temer en que la memoria vaya vacia de sus formas y figuras, que, pues Dios no tiene forma ni figura, según va vacía de formas y figuras, segura va vacía de formas y figuras y más acercándose a Dios; porque cuanto más se arrimare a la imaginación, más se aleja de Dios y en más peligro va, pues que Dios, siendo como es incogitable, no cabe en la imaginación" (Llama, III, 16). La referencia que en este libro se hace a san Gregorio, y precisamente para afirmar que "quien desea a Dios ya lo posee», nos permite entender que san Juan toma de S. 


\section{Experiencia normativa}

¿Es la experiencia de san Juan, en cuanto doctor de la mística, una norma para todos? El problema tiene diferentes significados. Nos preguntariamos ante todo, si todos están llamados a la mística. No cabe duda de que todos están invitados a la mística, como están invitados a la felicidad, a la virtud, a la riqueza, a la sabiduría, a la salud, y a cualesquiera bienes. Sin embargo, los caminos, profesiones, circunstancias, caracteres y ambientes son tan diferentes que los «místicos» es decir, los «profesionales de la mística» serán siempre una insignificante minoría. Con todo, la experiencia de san Juan será «normativa» para todos, es decir: cuando se afirma que hay «santos» que nunca tuvieron fenómenos místicos, había que demostrar la existencia de un solo sujeto, que haya cumplido todas las condiciones requeridas por Juan para su «camino" y no haya padecido fenómenos místicos. Eso no se ha demostrado y probablemente es indemostrable. La experiencia sanjuanista es pues normativa para los «místicos» consecuentes.

Se dirá que entonces, todos pueden ser «místicos» y así acaece en cierto modo: «todos pueden ser hijos de los profetas». Sin embargo, hay un problema previo de "vocación», que hay que tener en cuenta y Dios puede llamar a quien menos lo espera. Con todo hay que tener en cuenta lo que se da por supuesto en ambos extremos, el de Amós y el de Ezequiel, pues en ambos hay ya cualidades que entran en el concepto de vocación divina, y además, hay muchas posibilidades intermedias. Dios llama siempre, pero de diferentes modos, directos o indirectos. El hombre entra en la mística «cuando Dios quiere», pero Dios quiere cuando el hombre está dispuesto. $Y$ ya que cada profeta pertenece a un «movimiento profético», tenemos en san Juan una «experiencia normativa» también en este sentido.

Balthasar advierte que el problema suele simplificarse con exceso y así se hace insoluble. Porque si las situaciones de los hombres son muy «diferentes», la norma admitirá proporción y carácter diferente. No es lo mis-

Gregorio lo que aquí llamamos "doctrina de san Agustín», aunque no negamos las posibles dependencias directas. Del mismo modo, al orden de las potencias, entendimiento, voluntad y memoria, contrapone el Santo «inteligencia, amor y gloria» (Llama, III, 22), o también uinteligencia, amor y comunicación» (lb.). Y pues ellas realizan la unión, la sustancia no se opone realmente a las potencias, sino que las potencias entran en la sustancia del alma, y así tienen una gran dimensión inconsciente, como en san Agustín. Bien es verdad que esto se advierte y comprueba principalmente en la memoria. Y esto lo resume el santo en la teoria del urecuerdo» en su doble vertiente, en cuanto intima sustancia del alma y en cuanto movimiento producido por el verbo (L/ama, IV, 1 y 2): «Estando el alma en Dios sustancialmente, como lo está toda criatura, quítale de delante algunos de los muchos velos y cortinas, qué ella tiene antepuestos para poderle ver como él es; y entonces traslúcese y vese así algo entre oscuramente (porque no se quitan todos los velos) aquel rostro suyo.... (Llama, IV, 3). «Este recuerdo es... comunicación de la excelencia de Dios en la sustancia del alma, que es e/ seno suyo» (id, id). Dios mora pues siempre y secretamente en la memoria; pero a veces "recuerda», esto es, nos hace recordar" (Llama, IV, 5). 
mo la vida activa que la contemplativa, ni son lo mismo el ejercicio intelectual, la soledad del corazón, la concentración espiritual, la penitencia, etc. En cada caso la norma tendrá importancia e influencia desigual. Sería exagerado identificar las virtudes teologales con la contemplación infusa, identificar el campo teológico con el místico etc. La experiencia de san Juan es estrictamente normativa en su terreno propio, pero deberá aplicarse con precaución y prudencia en otros campos y situaciones. Lo importante es que todos y cada uno encuentran en san Juan y en la lectura de sus obras una "norma» útil e interesante. Llevadas las cosas al extremo es también claro que ni Cristo ni el evangelio son estrictamente una «norma» que todos deban "copiar»: por el contrario, tienen todos que traducir e interpretar esa norma, y así acontece que cada uno imita a Cristo o vive el evangelio a su propia manera. Pues eso mismo, con la debida proporción, podemos decir de san Juan, en cuanto es doctor de la mística. La fascinación que siempre ha producido su lectura demuestra que posee «el buen olor de Cristo» ${ }^{95}$.

\section{El canto del cisne}

Puesto que vivimos en régimen de fe, es inútil hablar de «mística de visión», como si el místico viese a Dios cara a cara, o como si su testimonio experimental tuviera fuerza lógica y objetiva acerca de la realidad y carácter de Dios. El místico, dice san Juan, tiene todavía tres telas que le impiden «ver a Diosı: la tela de las criaturas, la tela de las operaciones e inclinaciones naturales y la tela de la vida misma temporal ${ }^{96}$. De ahí deduce el santo que la muerte natural de los místicos perfectos es una «muerte de amor»: «no las arranca el alma, sino algún ímpetu y encuentro de amor, mucho más subido... pues pudo romper la (última) tela y llevarse la joya del alma» ${ }^{97}$. Para el místico, esa tela de la vida es ya tan delgada y trasparente, que es una tela de araña ${ }^{98}$. y que hace apetecible la muerte. "Y así la muerte de semejantes almas es muy suave y muy dulce, más que les fue la vida espiritual toda su vida, pues que mueren

95. Decimos que aunque la experiencia de san Juan de la Cruz es única, es también normativa y carismática (Cfr. BALTHASAR, I.c., p. 66 y PRZYWARA, E. Ringen der Gegenwart, 2 vols. Augsburg, 1929; I, 471s). La norma se aplicará, pues, «analógicamente» a diferentes situaciones y problemas espirituales. Así se deja a Dios la iniciativa de llevar a las almas por diferentes caminos, y al mismo tiempo se mantiene la referencia a la norma. Así la estrella polar o la brújula son normativas: aunque los navios no sigan estrictamente el rumbo marcado por ellas; ellas dan siempre un punto de referencia fijo y así permiten las aplicaciones y los cálculos.

96. Llama, I, 15.

97. Id., I, 16.

98. Id., I, 17. 
con más subidos ímpetus y encuentros sabrosos de amor, siendo ellas como el cisne, que canta más suavemente cuando se muere» ${ }^{99}$. San Juan debió asistir a la muerte de algunas de estas almas, y por su propia experiencia podía comprender bien la situación de san Pablo con el deseo de verse desatado y estar con Cristo. Se me antoja ver una referencia a santa Teresa de Jesús: «pocas almas llegan a tanto como esto, mas algunas han llegado, mayormen- te las de aquellos cuya virtud y espíritu se había de difundir en la sucesión de sus hijos, dando Dios la riqueza y valor a las cabezas en las primicias, según la mayor o menor sucesión que había de tener en su doctrina y espíritu» ${ }^{100}$. Por donde vemos que toda la mística de san Juan es parte del «movimiento carmelitano». Vemos, además, por qué al llegar a este libro de la Llama, el lenguaje del santo es también de fuego.

Es yạ claro que el «dolorido sentir» de Garcilaso nada tiene que ver con la "deficiencia constitutiva» de las criaturas, sino con la pena de los enamorados, que habían cantado tanta, veces el Petrarca y el mismo Garcilaso, y de un modo consuetudinario y apasionado los sufies ${ }^{101}$. Nada tiene eso que ver con las doctrinas de Enrique de Gante, aunque tampoco puede llamarse doctrina específicamente evangélica.

¿Cuál fue el éxito de san Juan de la Cruz? Dejando a un lado su éxito personal, le cabe la gloria de haber redondeado el movimiento carmelitano que creó en Castilla la figura del "carmelita», contrapuesta a la que había creado, también en Castilla, san Ignacio de Loyola con su «jesuita». Eran dos "hombres de frontera». Esos dos movimientos pudieron poner en pie a Castilla y renovar el mundo. Si no lo lograron, en gran parte se debió a los malos obreros que se empeñaron en arrancar lo que creían cizaña y arrancaron juntamente el trigo. Ni el carmelita ni el jesuita hallaron en Castilla la cogida que cabía esperar, y ese fue el fracaso, no de los santos, sino de la misma Castilla y de sus dirigentes «del partido de Dios». El tomișmo triunfó en las universida-

99. Id., 1, 16.

100. Id., II, 5. Hoy hablamos del "carisma del Fundador».

101. Por eso va desconcertada la opinión de Krynen. J., «De la teología humanística a la mística de las luces», en Religión y Cultura, 22 (1976) 465-484. Pero en san Juan se acentúa el dolorido sentir, como en los Sufíes, pues tenemos ya ante nosotros un "drama del Inconsciente» San Juan multiplica los calificativos: pena, pasión, desamparo, soledad, queja, desconsuelo, purgatorio, etc. Cfr. Noche, II, 5-8. Se llega incluso a la exageración (Noche, II, 13ss). Ya no basta el amor de la voluntad, sino que se desencadena la "pasión en la sustancia del alma», de modo que el alma parece enloquecida (Noche, II, 13,3). Ya hemos dicho que, aunque entran en acción las potencias, quedan también trascendidas en un inconsciente que es used, hambre y gloria de Dios). Lo que en el orden natural comienza por ser un inquietum cor, termina en furor porque se rompe «el último velo». Cfr. Noche, II, 8,1 y L/ama, I, 18). Por eso la memoria es el principio, pero también el fin, es decir, la esperanza o en esperanza. En la mística queda, pues, la naturaleza enteramente unificada, devuelta a la inocencia original del paraíso, en cuanto eso es posible, de algún modo. El místico se ve donándose al inconsciente y dejándose conducir por un extraño uinstinto racional», que ahora es natural y sobrenatural, al mismo tiempo: "jMáteme tu gracia y hermosura!». 
des castellanas e incluso se trató de obligar a san Juan de la Cruz a admitir el papel esencial de los "dones aristotélicos del Espíritu Santo», que analizará Juan de santo Tomás. Todos los caminos quedaron despejados para el Tomismo. Pero Castilla lejos de ponerse en pie, se tumbó ${ }^{102}$.

P. Lope Cilleruelo

102. Me asombra la facilidad con que algunos carmelitas atribuyen a san Juan de la Cruz la doctrina aristotélica de los «dones», olvidando la diferencia tomista entre "virtud» y "don». Los dones son necesarios, porque las virtudes son deficientes. Por lo visto, las virtudes teologales no valen para seguir las inspiraciones del espíritu Santo y necesitan "pedagogos» y antenas especiales. Claro que luego necesitamos una nueva moción "actual» para movilizar los mismos "dones»). (Cfr. P. Crisógono, La Escuela Carmelitana, p. 146). Para terminar, quisiera referirme a una obra que juzgo del mayor interés para seguir a san Juan de la Cruz. Es la Autobiografía del Licenciado Tomás G. de Mendoza. Su director fue el P. Juan Evangelista, compañero y discípulo de san Juan de la Cruz. La importancia de la Autobiografía es de muchas clases. Tampoco en ella se admite una visión facial, ni unos dones del Espíritu que expliquen la aparición de fenómenos místicos. En cambio se explica la relación del cuerpo en los fenómenos místicos, la subdivisión de la nomenclatura sanjuanista, etc. 